\title{
Using geographic distribution of well-screen depths and hydrogeologic conditions to identify areas of concern for contaminant migration through inactive supply wells
}

\author{
Robert M. Gailey ${ }^{1}$ (1) \\ Received: 29 June 2017 / Accepted: 14 January 2018 / Published online: 21 February 2018 \\ (C) The Author(s) 2018. This article is an open access publication
}

\begin{abstract}
Contaminant migration through inactive supply wells can negatively affect groundwater quality and the combined effects from groups of such wells may cause greater impacts. Because the number of wells in many basins is often large and the geographic areas involved can be vast, approaches are needed to estimate potential impacts and focus limited resources for investigation and corrective measures on the most important areas. One possibility is to evaluate the geographic distribution of well-screen depths relative to hydrogeologic conditions and assess where contaminant migration through wells may be impacting groundwater quality. This approach is demonstrated for a geographically extensive area in the southern Central Valley of California, USA. The conditions that lead to wells acting as conduits for contaminant migration are evaluated and areas where the problem likely occurs are identified. Although only a small fraction of all wells appear to act as conduits, potential impacts may be significant considering needs to control nonpoint-source pollution and improve drinking water quality for rural residents. Addressing a limited number of areas where contaminant migration rates are expected to be high may cost-effectively accomplish the most beneficial groundwater quality protection and improvement. While this work focuses on a specific region, the results indicate that impacts from groups of wells may occur in other areas with similar conditions. Analyses similar to that demonstrated here may guide efficient investigation and corrective action in such areas with benefits occurring for groundwater quality. Potential benefits may justify expenditures to develop the necessary data for performing the analyses.
\end{abstract}

Keywords Wellbore leakage $\cdot$ Contamination $\cdot$ Geographic information systems $\cdot$ Screening evaluation $\cdot$ USA

\section{Introduction}

Contaminant migration through inactive supply wells can negatively affect groundwater quality (Landon et al. 2009; Mayo 2010; Jurgens et al. 2014; Zuurbier and Stuyfzand 2017; see Gailey 2017 for a detailed literature review). With the exception of Clark et al. (2008), studies on wells that act as conduits for contaminant migration address single wells; however, the combined effects of groups of wells may cause greater impacts (Gailey 2017). Because the number of wells is often large and the geographic areas can be vast, approaches are needed to

Robert M. Gailey

rmgailey@ucdavis.edu

1 Department of Civil and Environmental Engineering, University of California Davis, 2001 Ghausi Hall, 1 Shields Avenue,

Davis, CA 95616, USA evaluate potential impacts and focus limited resources on investigations and corrective measures where most beneficial.

Recent and developing advances in data accessibility may allow survey-level screening to guide work on groundwater management including addressing conduit wells. Early examples include (1) Perrone and Jasechko (2017) who compiled well depth information from 17 databases in western USA and evaluated the incidence of wells going dry during drought and (2) Jasechko et al. (2017) who used a combination of well depth data and water quality information from across the globe to assess water supply vulnerability to contamination. Ongoing efforts to increase accessibility for data pertinent to groundwater management in California, USA are considered by Cantor et al. (2018). The work presented here considers the geographic distribution of conditions that result in wells acting as conduits and evaluates potential magnitudes of contaminant migration in particular areas. To the best of the author's knowledge, such work has not been performed before. Application to the southern Central Valley of California (Fig. 1) is presented as a demonstration example. 
Fig. 1 Study area in California, USA. Gray shaded area indicates approximate extent of Corcoran Clay (study area)

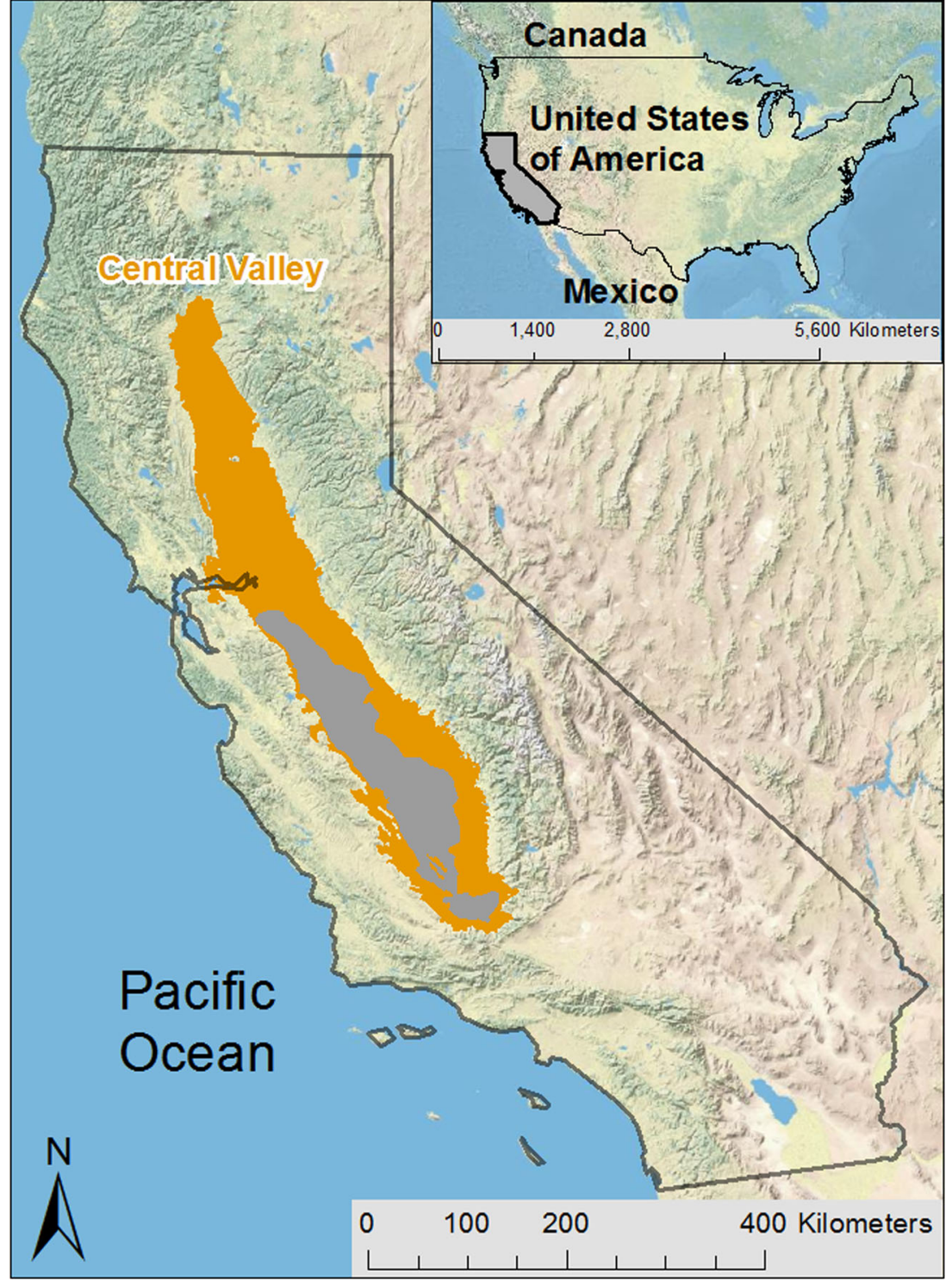

\section{Study area}

California's southern Central Valley supports intensive agricultural activity with heavy reliance on groundwater for irrigation (Hanak et al. 2017). The shallower freshwater part of the groundwater system comprises an interfingered assemblage of alluvial and flood-basin deposits that is approximately $1,000 \mathrm{~m}$ thick and exists under semiconfined conditions (Faunt 2009). Groundwater overdraft in the region (CADWR 2016; Hanak et al. 2017) combined with pumping at depth and resistance to vertical flow by numerous silt and clay aquitards including the regionally extensive Corcoran Clay (CADWR 1981; Page 1986; Faunt 2009; Fig. 1) has resulted in pronounced and geographically extensive decreases in head with depth for the past many decades (Davis et al. 1964; Belitz and Heimes 1990; Faunt 2009). Shallow groundwater quality is generally poor as a result of agricultural activities while deeper water quality is often better (Faunt 2009; Landon et al. 2009; Moore et al. 2011). Deeper supply wells crossing lowhydraulic conductivity layers including the Corcoran Clay may act as conduits for vertical migration of contaminants under these conditions (Davis et al. 1964; Faunt 2009). Given the many wells, variability in conditions with location, and the large extent of the study area (approximately $6,600 \mathrm{mi}^{2}$ or $17,100 \mathrm{~km}^{2}$ ), assessment of potential for vertical contaminant migration would provide useful information to evaluate the need for investigation and corrective action in particular parts of the study area.

\section{Data sources and methods of analysis}

As discussed by Gailey (2017), wells act as conduits for contaminant migration under the following conditions (Fig. 2): (1) differences in head and water quality exist between water-bearing strata over a vertical section, (2) stratification of high- and low-hydraulic 
Fig. 2 Schematic of well that acts as a conduit for flow and solute transport. Blue symbols indicate piezometric levels at different depths in the groundwater system. Green arrows indicate relatively rapid flow between water-bearing strata through the well (shortcircuiting flow)

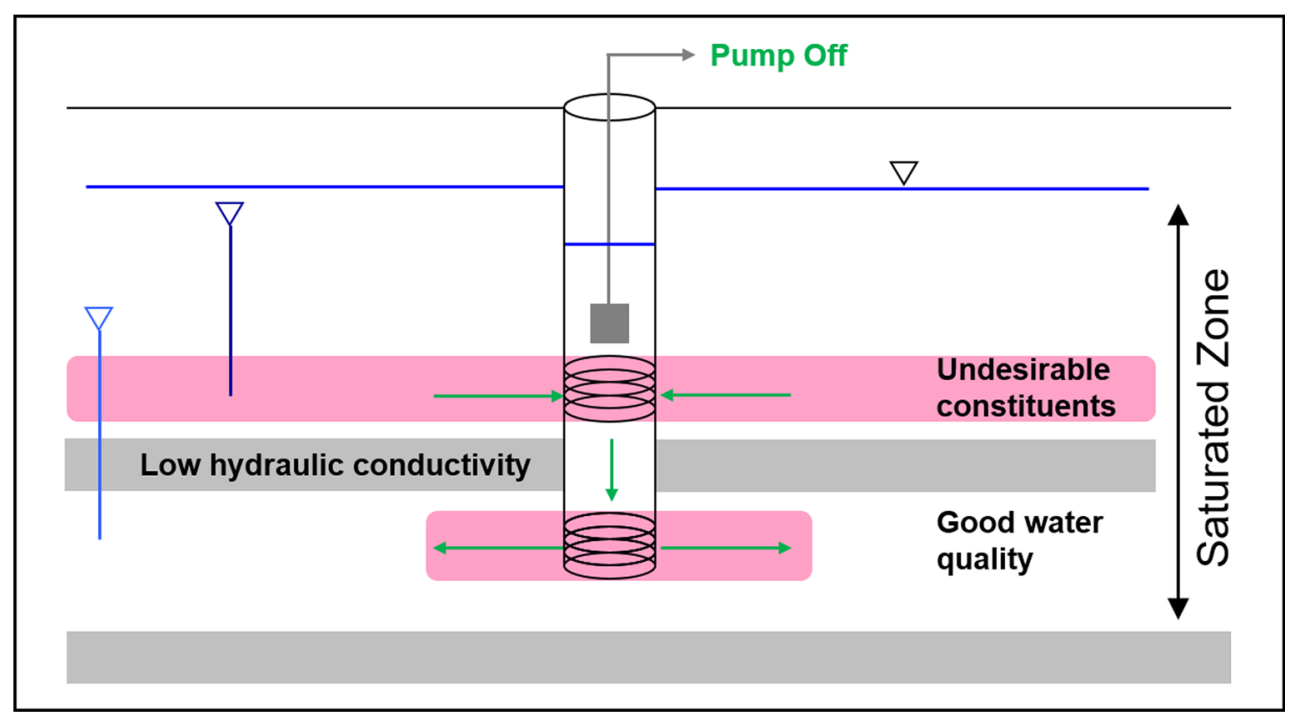

conductivity sediments impede vertical flow and solute transport and (3) the screened intervals of wells vertically span the stratigraphy allowing relatively rapid vertical flow between waterbearing strata to occur through the wells (short-circuiting flow). This work focuses on the Corcoran Clay as a point of reference for defining such vertical flows in the study area; however, it is noted that short-circuiting of other low-hydraulic conductivity strata and subsequent contaminant migration may also occur above the Corcoran Clay.

\section{Data sources}

Data on the afore-referenced conditions are available for locations across the study area from a variety of sources. Decreases in head with depth can be evaluated using groundwater level data available from the California Department of Water Resources (CADWR 2017a). These data were downloaded as spreadsheet files. Variations in shallow groundwater quality (above the Corcoran Clay) are documented for nitrate and total dissolved solids (TDS) by the Central Valley Salinity Coalition (CVSC 2016). These data were obtained as geographic information system (GIS) layers through an information request to the CVSC. Stratigraphic information, consisting of depths from ground surface to the top and thicknesses of the Corcoran Clay, is documented by Faunt (2012). These data were downloaded as GIS layers. For supply wells, screened intervals, specified by depths from ground surface to the tops of the shallowest and bottoms of the deepest screened sections, casing diameters and approximate locations are documented by the CADWR (CADWR 2017b). These data were obtained as spreadsheet files through an information request to the CADWR.

\section{Methods of analysis}

Two types of analysis are performed for this work. First, information on the geographic distributions of different data related to short-circuiting flow in wells are evaluated, localized areas are identified where conditions for such flow appear to exist, and rates of contaminant transfer to deeper strata are estimated. Second, the potential significance of the estimated flows and contaminant transfer rates through individual wells are evaluated within the context of the much larger groundwater system.

\section{Evaluating geographic information}

The method presented here identifies geographic coincidence of the different conditions necessary for migration through well conduits. The conditions are evaluated at a horizontal resolution limited to $1 \mathrm{mi}^{2}\left(2.6 \mathrm{~km}^{2}\right)$ as a result of censored well location accuracy in the dataset available for this study. Seven data processing steps use a combination of GIS software and spreadsheets with macro scripts to generate results. The workflow is summarized on Fig. 3 and described in the following list in detail.

1. Screened-interval data for all supply well types in the dataset (agricultural, industrial, municipal and domestic) are available with locations cataloged according to US Public Land Survey System (PLSS) grid at the section level. Because the State of California limits well location information to this $1 \mathrm{mi}^{2}\left(2.6 \mathrm{~km}^{2}\right)$ grid to protect well owner privacy, the maximum horizontal resolution of this study is limited to the same. The screened-interval depth and well type data are aggregated and mapped onto the PLSS section grid.

2. The data for water quality in the shallower water-bearing zone (above the Corcoran Clay) are mapped onto the PLSS grid. Contoured representations of the water quality data are available as GIS polygon shapefiles on a grid of similar horizontal resolution as the PLSS (CVSC 2016). These data are spatially joined to the PLSS grid. 


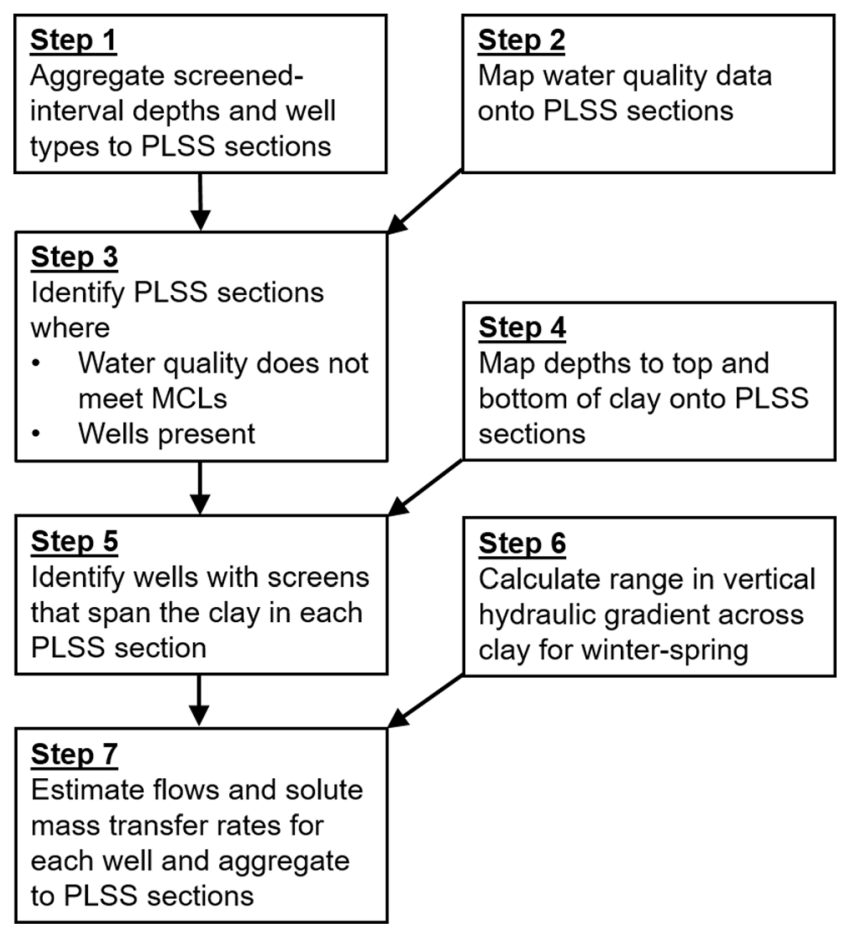

Fig. 3 Work flow for evaluating geographic information

3. Lists of PLSS sections thatmeet two criteria are compiled.

a. Water quality constituent concentrations exceed the maximum contaminant level (MCL) for nitrate, TDS or both.

b. At least one well of any depth is present.

4. Depths to the top and bottom of the Corcoran Clay are mapped onto the PLSS grid. Contoured representations of the depth to top and thickness of the clay, available as GIS polyline shapefiles (Faunt 2012), are rasterized and converted to GIS polygon shapefiles with values specified for each cell on the PLSS grid. Depth to the bottom of the clay is then calculated for each grid cell as the sum of depth to top and thickness of the clay.

5. The number of likely conduit wells is recorded for each PLSS section where water quality does not meet MCLs. a. Well construction data for each PLSS section in the lists from step 3 are accessed.

b. Depths to top and bottom of screened intervals are compared to depths to top and bottom of clay for the PLSS section.

c. Wellswith screens that vertically span the thickness of the Corcoran Clay in each PLSS section are aggregated and mapped to the PLSS grid.

6. Vertical head differences and hydraulic gradients across the Corcoran Clay are calculated for the winter-spring when wells are most often idle and potentially act as conduits. Groundwater levels are initially selected from the available monitoring well dataset if they meet all of the following information

requirements: PLSS section location, screenedinterval depths and water level data available for winter-spring. The selected data are then culled based upon the following criteria: PLSS section has data from both above and below the Corcoran Clay, data above and below clay occur during winter-spring of the same year, data occur during 2012 to 2016. Because monitoring wells screened above and below the clay are generally not at the same location, data aggregation is necessary. For each PLSS section where data meeting the aforereferenced requirements are available, averages are calculated for the following quantities: heads above the clay, depths to bottoms of screened intervals above the clay, heads below the clay and depths to tops of screened intervals below the clay. A vertical gradient is then calculated for each PLSS section:

$i_{\text {clay }}=\left(H_{\text {above }}-H_{\text {below }}\right) /\left(D_{\text {screen_bottom_above }}-D_{\text {screen_top_below }}\right)$

where the terms are as follows:

$i_{\text {clay }}$

$H_{\text {above }}$

$H_{\text {below }}$

$D_{\text {screen bottom above }}$

$D_{\text {screen_top_below }}$
Estimated vertical hydraulic gradient across the clay Average head above the clay Average head below the clay Average depth to bottom of well screen above the clay Average depth to top of screen below the clay

7. Flows and mass transfer rates through conduit wells fromstrata above the Corcoran Clay to those beneath the clay are estimated across the study area.

a. Effective hydraulic conductivity estimates are generated for all wells with screened intervals that span the Corcoran Clay. Well diameter data are used with the Hagen-Poiseuille equation to perform the calculations (Appendix; Gailey 2017).

b. Flow rates are estimated for each well using Darcy's Law with information developed in the preceding text:

$Q_{\text {well_est }}=K_{\text {well }} i_{\text {clay }} A_{\text {well }}$

where the terms are as follows:

$Q_{\text {well_est }} \quad$ Estimated flow rate through the well

$K_{\text {well }} \quad$ Effective hydraulic conductivity for the well

$A_{\text {well }} \quad$ Well casing cross sectional area calculated from the well diameter

High and low values for the vertical gradient across the study area (calculated in step 6) are used as the basis to estimate a range in flow rate for each well. These vertical gradients are scaled by a factor of $2 \times 10^{-6}$ based on calculations presented in the Appendix: 
$Q_{\text {well_est }}=K_{\text {well }} f_{\text {scale }} i_{\text {clay }} A_{\text {well }}$

where $f_{\text {scale }}$ is the gradient scaling factor

The scaling is necessary because gradients associated with flow through well casings are typically much lower than vertical gradients in groundwater systems at some distance from the wells as a result of (1) decreased resistance to vertical flow within the casing relative to naturally layered groundwater systems and (2) head losses related to passage through well screens and (3) convergent (divergent) flow to (from) the well through the porous medium. Over estimation of flow rates occurs unless the gradient is reduced (Gailey 2017).

c. Rates of nitrate and TDS transfer across the clay are calculated for each well as the product of flow through the well and concentration in the PLSS section.

d. The flows and transfer rates, initially calculated for the period of one day, are then scaled up to a 180-day period (multiplied by 180). The upscaling is performed to represent the amount of time that wells are generally idle and potentially act as conduits each year during the low demand season. The results are then aggregated for each PLSS section and the study area as a whole.

\section{Comparing regional and well-specific fluxes}

Two numerical groundwater flow and solute transport models presented by Gailey (2017) are used to compare the relative magnitudes of groundwater volumetric flows, fluxes per unit area (Darcy velocities) and extent of water quality impact from solute mass transfer through (1) regional aquitards and (2) wells that act as conduits. The models simulate a hypothetical groundwater system comprising two aquifers and an intervening aquitard. The first model simulates steady-state heads when no conduit well is present. The second model uses the steady-state heads as initial conditions to simulate transient flow and advective transport where (1) no conduit well is present and (2) an idle water supply well cross-connects the aquifers. A single 180-day stress period is simulated. Table 1 summarizes the model parameters. Additional details regarding the model structure are presented in Gailey (2017).

Given the variation in conditions in the study area (Page 1986; Faunt 2009) and the simplified representation of aquifer system hydrostratigraphy in the modeling, the aquitard hydraulic conductivity is varied to evaluate the potential range of groundwater volumetric flows, fluxes per unit area and solute mass transferrates. The vertical hydraulic conductivity of the aquitard is changed over four orders of magnitude (with the horizontal hydraulic conductivity remaining one order of magnitudehigher that the verticalhydraulic conductivity)and groundwater volumetric flow and flux per unit area are recorded for (1) the aquitard when the well is not present, (2) the aquitard and the well when the well is present. Flow through the aquitard is recorded for the entire model domain (considered two times the simulated half-space dimensions presented in Table 1) and flux is the average over the domain. The length of the solute plume in the lower aquifer resulting from the well acting as a conduit is also recorded - taken as the maximum length parallel to the direction of groundwater flow where concentrations exceed the background value of $10 \mathrm{mg} / \mathrm{l} \mathrm{pre-}$ sented in Table 1 . Sensitivity of the solute transport results to the horizontal hydraulic conductivity of the aquifers is also evaluated by repeating the calculations for an order of magnitude reduction in the values used for the aquifer horizontal hydraulic conductivity - aquifer horizontal hydraulic conductivity reduced from $10^{-2}$ to $10^{-3} \mathrm{~cm} / \mathrm{s}$ with the vertical hydraulic conductivity remaining one order of magnitude lower than the horizontal hydraulic conductivity.

\section{Limitations}

The approach for section 'Evaluating geographic information' assumes that the available datasets regarding water quality, stratigraphy and hydraulic head reasonably characterize the hydrogeologic conditions at the scale of PLSS sections $\left(1 \mathrm{mi}^{2}\right.$, or $2.6 \mathrm{~km}^{2}$ ). These data are available at horizontal resolutions generally lower than the PLSS grid and interpretations, guided by the professional judgment of the author (for representative ranges for vertical hydraulic gradients) and others (for contours of clay depth and thickness as well as water quality constituents obtained for this work), are applied. Additional interpretations are made with regard to the well data. Because no comprehensive well destruction records are available, all wells in the well construction dataset are used in the analysis. This aspect of the approach tends towards a conservatively high estimate of the effects from well conduits, as it is possible that some of the wells included in the analysis have been properly destroyed and may no longer exist as potential conduits. However, other wells not identified by this approach may act as conduits because of (1) localized occurrences of nitrate and TDS not included in the water quality information used here, (2) other contaminants not considered and (3) well constructions with long gravel packs that short-circuit the Corcoran Clay; transport along gravel packs could be considered if data on this aspect of the well constructions were available. It should also be noted that short-circuiting flow and contaminant migration relative to other low-hydraulic conductivity strata above the Corcoran Clay may also occur but is not the focus of this work. These potential limitations could be addressed through use of additional data that may become available in the future. Since the purpose of the approach is developing indications of where concern may be warranted so that 
Table 1 Numerical model parameters

\begin{tabular}{lll}
\hline Parameter category & Parameter & Value \\
\hline Half-space domain dimensions & Width & $628 \mathrm{~m}$ \\
Length & Depth & $1,638 \mathrm{~m}$ \\
Upper and lower & Thickness & $75 \mathrm{~m}$ \\
aquifer parameters & Horizontal hydraulic conductivity & $30 \mathrm{~m}$ \\
& Vertical hydraulic conductivity & $10^{-2} \mathrm{~cm} / \mathrm{s}$ \\
& Storage coefficient & $10^{-3} \mathrm{~cm} / \mathrm{s}$ \\
& Porosity & $10^{-4}$ \\
& Recharge (upper) & 0.3 \\
& Initial concentration (upper) & $9 \times 10^{-4} \mathrm{~m} / \mathrm{d}$ \\
& Initial concentration (lower) & $100 \mathrm{mg} / 1$ \\
Aquitard parameters & Thickness & $10 \mathrm{mg} / 1$ \\
& Horizontal hydraulic conductivity & $15 \mathrm{~m}$ \\
& Vertical hydraulic conductivity & $10^{-5} \mathrm{~cm} / \mathrm{s}$ \\
& Storage coefficient & $10^{-6} \mathrm{~cm} / \mathrm{s}$ \\
& Porosity & $10^{-4}$ \\
Hydraulic gradients & Initial concentration & 0.3 \\
& Gravel pack hydraulic conductivity & $100 \mathrm{mg} / 1$ \\
& Casing hydraulic conductivity & $1 \mathrm{~cm} / \mathrm{s}$ \\
& Horizontal in aquifers & $100 \mathrm{~cm} / \mathrm{s}$ \\
& Vertical across aquitard & 0.001 \\
& & -0.15 \\
\hline
\end{tabular}

potential conduit wells can be considered in more detail, the limitations identified here are reasonable.

The approach for section 'Comparing regional and well-specific fluxes' assumes (1) simplified stratigraphy, (2) fairly low vertical hydraulic gradient and casing hydraulic conductivity compared to what is possible in the field and (3) only a single well conduit. As a result, the predicted flows and fluxes through the conduit well may be low relative to what could occur in the field. The predicted plume lengths may also be shorter than occur in some field cases as a result of the lower flow rates, lack of simulated heterogeneity in aquifer hydraulic conductivity, and no comingling of plumes from multiple conduit wells. While these limitations may result in underestimation of the flows and water quality impacts from conduit wells, conceptual demonstration of how such wells interact with the greater groundwater system is still achieved.

\section{Results and discussion}

\section{Conditions creating potential for conduit migration}

The results from steps 1-3 of section 'Evaluating geographic information' provide the initial information regarding conditions that create potential for conduit migration. Figure 4a,b summarizes the distributions of nitrate and TDS concentrations present above the clay. Nitrate concentrations above the MCL (10 mg/l nitrate as nitrogen) are anthropogenic while the TDS concentrations above the MCL (500 mg/l) may result from natural processes in some cases, particularly in the western part of the study area (CVSC 2016). Figure 5a,b summarizes the depth to top and thickness of the Corcoran Clay. In general, the clay is deepest in the central part and on the west side of the study area and also thickest on the west side.

The well construction data indicate 33,579 supply wells within the extent of the Corcoran Clay (Fig. 6a) including 15,024 agricultural; 428 industrial; 804 municipal and 17,323 domestic wells. Many of these wells (22,570 in total) terminate below the clay and decrease heads below the clay when pumped. The vast majority of these wells are agricultural (11,763 or 52\%; Fig. 6b) and domestic (9902 or 44\%; Fig. 6c). Downward vertical gradients drive flows through wells with screened intervals that span the clay thickness (2693 wells; Fig. 6d). These wells tend to be located where the clay is shallower (Fig. 5a) and thinner (Fig. 5b). Areas where supply wells of any depth are present and water quality does not meet the MCLs for nitrate, TDS or both constituents are indicated on Figs. $7 \mathrm{a}-\mathrm{c}$. These results, generated from step 3 of section 'Evaluating geographic information', provide the basis for evaluating whether wells in specific areas may act as conduits for contaminant migration. For nitrate, 12,005 wells, or $36 \%$ of all wells, are located in PLSS sections where the MCL is exceeded. There are 9,105 wells $(27 \%)$ that are located in sections with TDS 

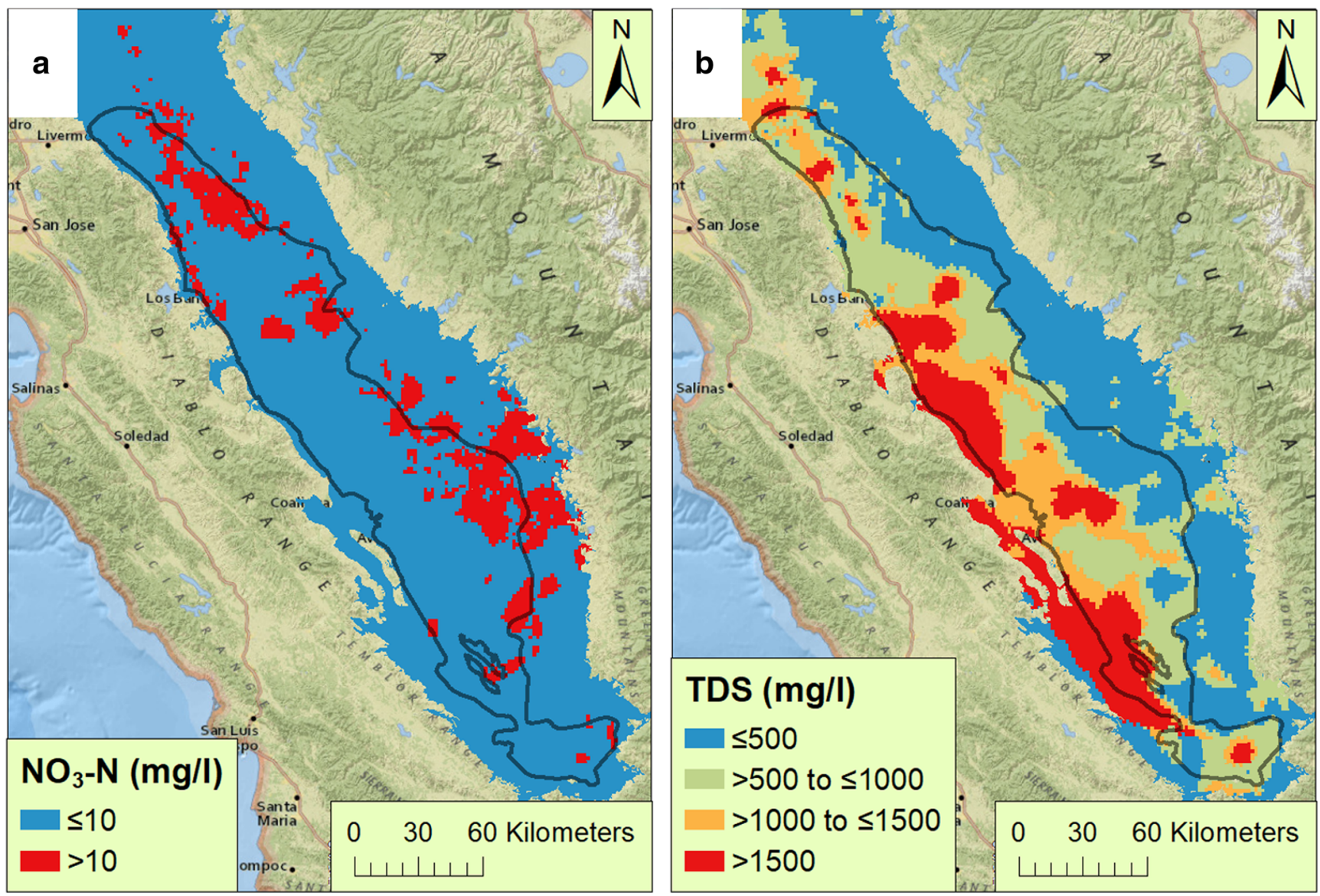

Fig. 4 Groundwater quality above the clay: a nitrate as nitrogen $\left(\mathrm{NO}_{3}-\mathrm{N}\right)$ and $\mathbf{b}$ total dissolved solids (TDS). Black line indicates approximate extent of Corcoran Clay. Maximum contaminant level for nitrate as nitrogen is $10 \mathrm{mg} / \mathrm{l}$ and for total dissolved solids is $500 \mathrm{mg} / \mathrm{l}$. Data from CVSC (2016)

exceedance and 5,557 wells (17\%) are located in sections with exceedance of both constituents.

\section{Areas of concern}

Results from steps 4 and 5 of section 'Evaluating geographic information' suggest the areas of concern defined by sections that have (1) concentrations above the MCLs and (2) wells likely acting as conduits. For nitrate, 875 wells located in 430 PLSS sections are constructed such that they may act as conduits for contaminant migration (Fig. 8a), which is $3 \%$ of the wells within the extent of the Corcoran Clay and $7 \%$ of the wells where water quality does not meet the MCL. A notable cluster of wells is present southwest of the city of Visalia and there are smaller clusters throughout the study area. For TDS, 1505 wells in 817 PLSS sections may act as conduits (Fig. 8b). This is $5 \%$ of the wells within the extent of the Corcoran Clay and $17 \%$ of the wells where water quality does not meet the MCL. While some of the areas of concern overlaps with those for nitrate, the spatial distribution of areas of concern for TDS is different from that of nitrate. Notable clusters of wells are present south of the city of Merced as well as in the southernmost part of the study area. As shown in Fig. 8c, 418 wells in 222 sections are constructed such that they may act as conduits for both constituents. This is $1 \%$ of the wells within the extent of the Corcoran Clay and $8 \%$ of the wells where water quality does not meet both MCLs. There are small clusters of these wells throughout the study area.

The breakdown of well types that may act as conduits (Table 2) indicates that the majority of wells are agricultural; however, a notable number of domestic wells may also act as conduits. In addition, comparison of Fig. 6b,c with Fig. 8a-c indicates the types of wells potentially impacted by migration through conduits. While both agricultural and domestic wells draw water from beneath the Corcoran Clay throughout the study area and are subject to contamination spreading from wells that act as conduits, water quality requirements are generally more stringent for the domestic wells. The density of domestic wells in the northern portion of the study area near Merced (Fig. 6c) may be a particular concern for the spread of nitrate contamination from conduit wells (Fig. 8a).

Vertical head differences and gradients across the clay during the winter-spring are summarized in Fig. 9 a,b. The magnitudes of the head differences are consistent with previous findings (Davis 

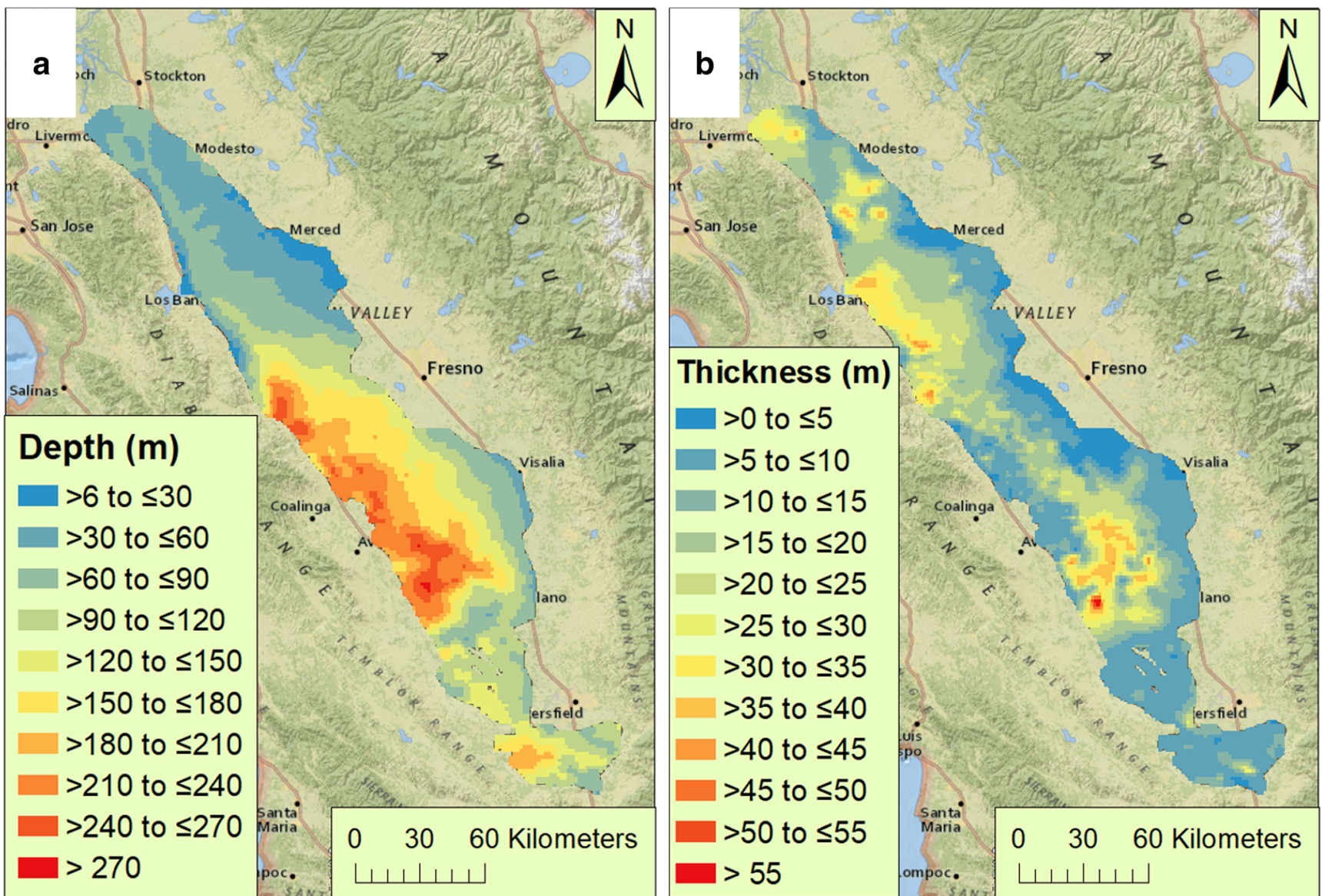

Fig. 5 Corcoran clay: a depth to top of the clay and $\mathbf{b}$ thickness of clay. Data from Faunt (2012)

et al. 1964). Likewise, the calculated gradients are supported by previous work (Phillips and Belitz 1991). Calculations are made for 29 PLSS sections where sufficient data are available, generally between the years 2013 and 2016. Gradients in the range of -0.5 to -0.1 cover most of the observed variation (69\%) and occur throughout the study area. These values are used to estimate ranges in flows for each conduit well.

Results from step 7 of section 'Evaluating geographic information' provide estimates for groundwater volumetric flows and contaminant mass transfer rates for the likely conduit wells. Conduit flows range between $5.6 \times 10^{7}$ and $2.8 \times 10^{8} \mathrm{~m}^{3} / 180 \mathrm{~d}$ for the study area as a whole. Individual PLSS sections range between $5.0 \times 10^{\circ}$ and $4.8 \times 10^{6} \mathrm{~m}^{3} / 180 \mathrm{~d}$ or approximately 0 to $1.7 \%$ of the study area total (Table 3 and Fig. 10a). The average flow through one of the 2693 conduit wells on Fig. 6d (calculated by dividing the low and high estimated flows for the study area in Table 3 by the number of conduit wells) ranges from $8.1 \times 10^{1}$ to $4.0 \times 10^{2} 1 / \mathrm{min}$ and is not uncommon for the area (Gailey 2017). The resulting nitrate transfer rates range between $4.2 \times 10^{5}$ and $2.1 \times$ $10^{6} \mathrm{~kg} / 180 \mathrm{~d}$ for the study area. Individual PLSS sections range between $2.3 \times 10^{-2}$ and $3.0 \times 10^{4} \mathrm{~kg} / 180 \mathrm{~d}$ or approximately 0 to $1.5 \%$ of the study area total (Table 3 and
Fig. 10b). TDS transfer rates range between $5.1 \times 10^{7}$ and $2.5 \times 10^{8} \mathrm{~kg} / 180 \mathrm{~d}$ for the study area. Individual PLSS sections range between $9.2 \times 10^{-1}$ and $6.7 \times 10^{6} \mathrm{~kg} / 180$ $\mathrm{d}$ or approximately 0 to $2.6 \%$ of the study area total (Table 3 and Fig. 10c). These flows and transfer rates are in addition to those that occur through the Corcoran Clay itself.

\section{Well-specific versus regional fluxes and impacts on water quality}

The maximum number of wells with screens that span the Corcoran Clay in a PLSS section is 10 (Fig. 6d); therefore, the area covered by the Corcoran Clay is far larger than the combined cross-sectional area of the conduit well casings. The results of numerical modeling (see section 'Comparing regional and wellspecific fluxes') demonstrate that this difference in areas is so great that it is expected to outweigh differences in other Darcy Law terms for flows through the aquitard and well (hydraulic conductivity and gradient). For most conditions, volumetric flow through the aquitard is expected to exceed that through a conduit well (Fig. 11). This is true for the aquitard geology in the study area where variations in lithology (Page 1986 and Fig. 5b) result 

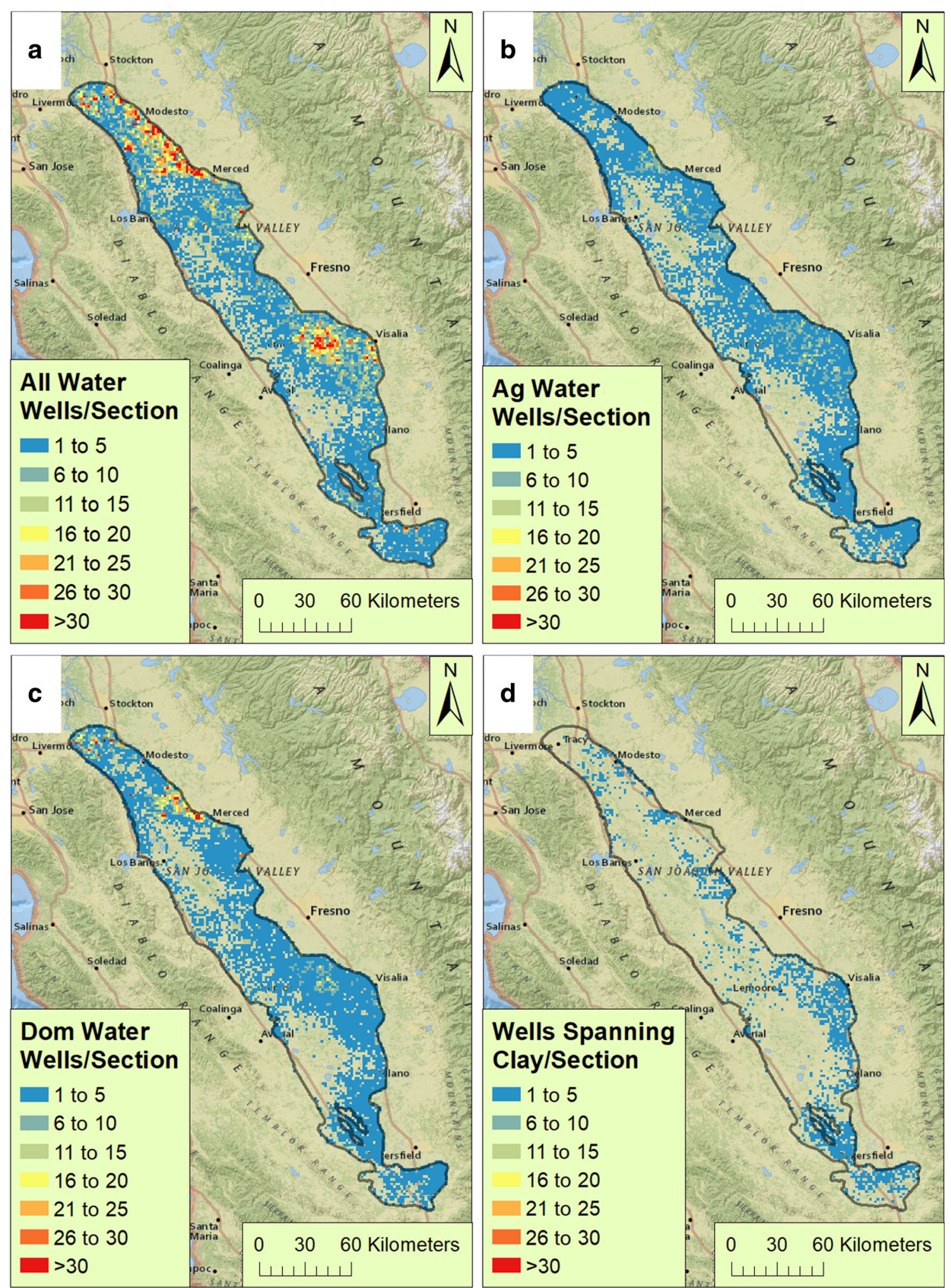

Fig. 6 Supply wells in the study area: a all wells located within the extent of Corcoran Clay, b agricultural wells that terminate beneath the clay, c domestic wells that terminate beneath the clay and $\mathbf{d}$ total wells with

screened intervals that span the clay. Black line indicates approximate extent of Corcoran Clay 

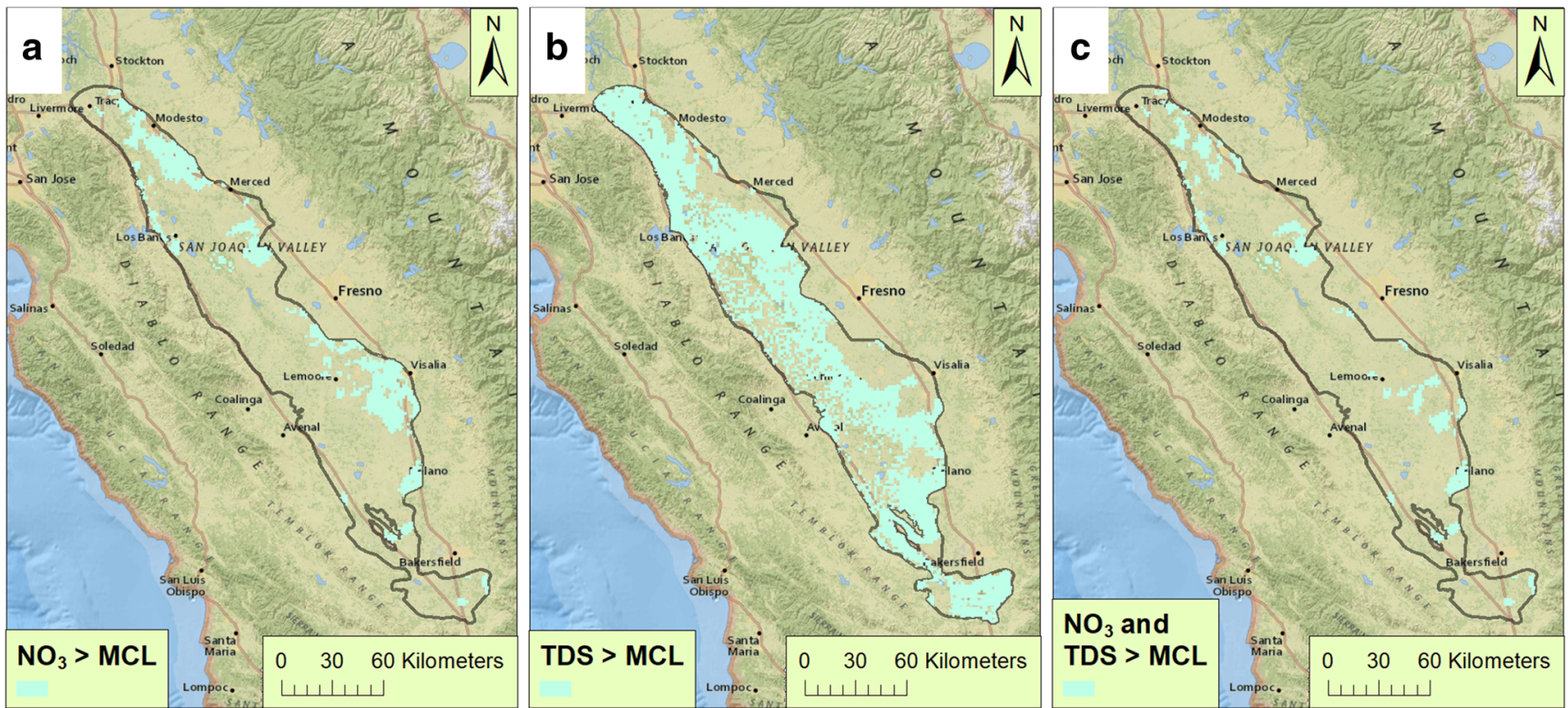

Fig. 7 Areas where supply wells are present and water quality does not meet MCLs: a nitrate, $\mathbf{b}$ total dissolved solids and $\mathbf{c}$ both constituents. Black line indicates approximate extent of Corcoran Clay
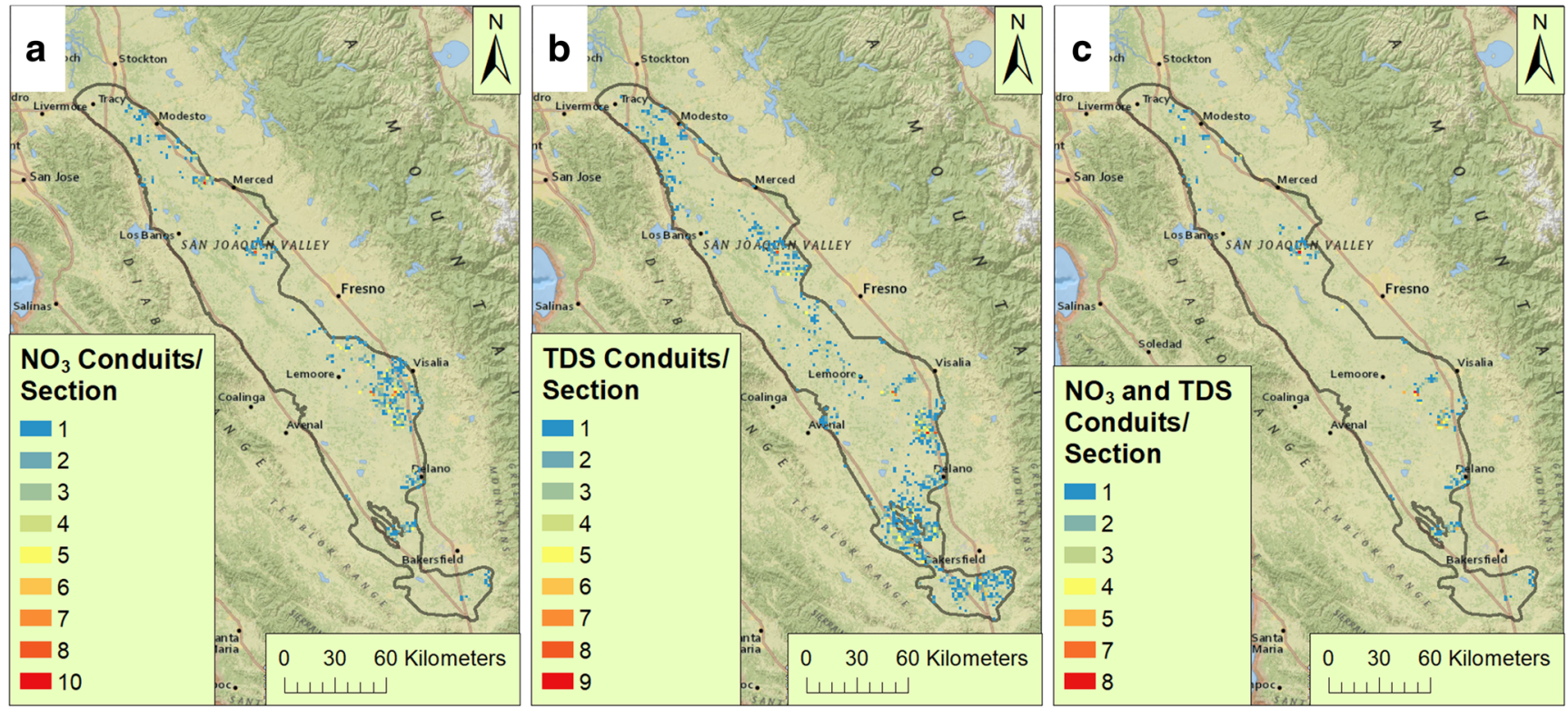

Fig. 8 Supply wells that may act as conduits: a nitrate, $\mathbf{b}$ total dissolved solids and $\mathbf{c}$ both constituents. Black line indicates approximate extent of Corcoran Clay

in local vertical hydraulic conductivities for the aquitard that likely allow leakage (i.e., $K_{\mathrm{v}}>\sim 10^{-6} \mathrm{~cm} / \mathrm{s}$ on Fig. 11). However, comparison of groundwater fluxes calculated by normalizing the volumetric flow rate by the area (Darcy velocities) indicates that flux through conduit wells is many orders of magnitude greater than through the aquitard (Fig. 12). While flux through the well is
Table 2 Number of wells potentially acting as conduits where MCL exceeded

\begin{tabular}{llllll}
\hline Constituent & Total & Agricultural & Industrial & Municipal & Domestic \\
\hline Nitrate & 875 & 711 & 9 & 10 & 145 \\
TDS & 1,505 & 1,280 & 27 & 17 & 181 \\
Both & 418 & 353 & 7 & 6 & 52 \\
\hline
\end{tabular}



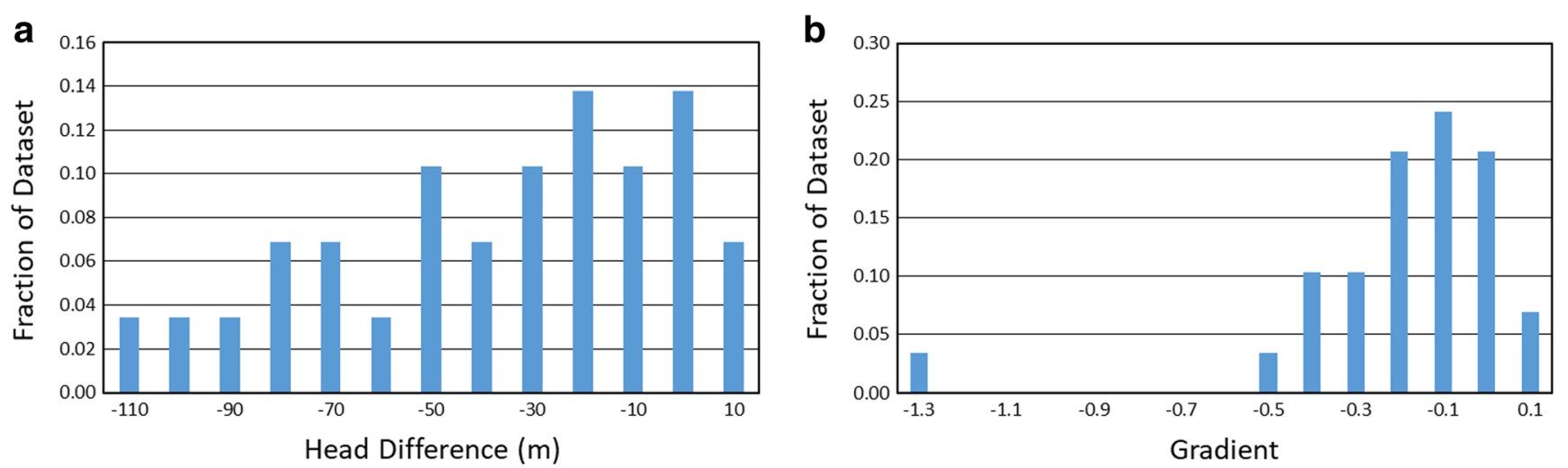

Fig. 9 Hydraulic changes across the Corcoran Clay: a vertical head difference and $\mathbf{b}$ vertical gradients. Negative values indicate that head is lower beneath the clay than above the clay

Table 3 Estimated transfer rates through potential conduit wells

\begin{tabular}{|c|c|c|c|c|c|c|}
\hline \multirow[t]{2}{*}{ Location } & \multicolumn{2}{|c|}{ Water $\left(\mathrm{m}^{3} / 180 \mathrm{~d}\right)$} & \multicolumn{2}{|c|}{$\mathrm{NO}_{3}-\mathrm{N}(\mathrm{kg} / 180 \mathrm{~d})$} & \multicolumn{2}{|c|}{ TDS (kg/180 d) } \\
\hline & Low & High & Low & High & Low & High \\
\hline Study area & $5.6 \times 10^{7}$ & $2.8 \times 10^{8}$ & $4.2 \times 10^{5}$ & $2.1 \times 10^{6}$ & $5.1 \times 10^{7}$ & $2.5 \times 10^{8}$ \\
\hline \multirow[t]{2}{*}{ Min section } & $5.0 \times 10^{0}$ & $2.5 \times 10^{1}$ & $2.3 \times 10^{-2}$ & $1.2 \times 10^{-1}$ & $9.2 \times 10^{-1}$ & $4.6 \times 10^{0}$ \\
\hline & $0 \%$ & $0 \%$ & $0 \%$ & $0 \%$ & $0 \%$ & $0 \%$ \\
\hline \multirow[t]{2}{*}{ Max section } & $9.7 \times 10^{5}$ & $4.8 \times 10^{6}$ & $6.1 \times 10^{3}$ & $3.0 \times 10^{4}$ & $1.4 \times 10^{6}$ & $6.7 \times 10^{6}$ \\
\hline & $1.7 \%$ & $1.7 \%$ & $1.5 \%$ & $1.5 \%$ & $2.6 \%$ & $2.6 \%$ \\
\hline
\end{tabular}

Columns designated as Low present calculations using a vertical gradient of -0.1 . Columns designated as High present calculations using a vertical gradient of -0.5 . Areas for the study area and a section are 17,100 and $2.6 \mathrm{~km}^{2}$, respectively. Percentages are relative to the study area values.

sensitive to the value of aquitard hydraulic conductivity, significant difference between the conductivities of the well and the aquitard remains over a reasonable range of aquitard conductivities and the flux through the well is greater by orders of magnitude.
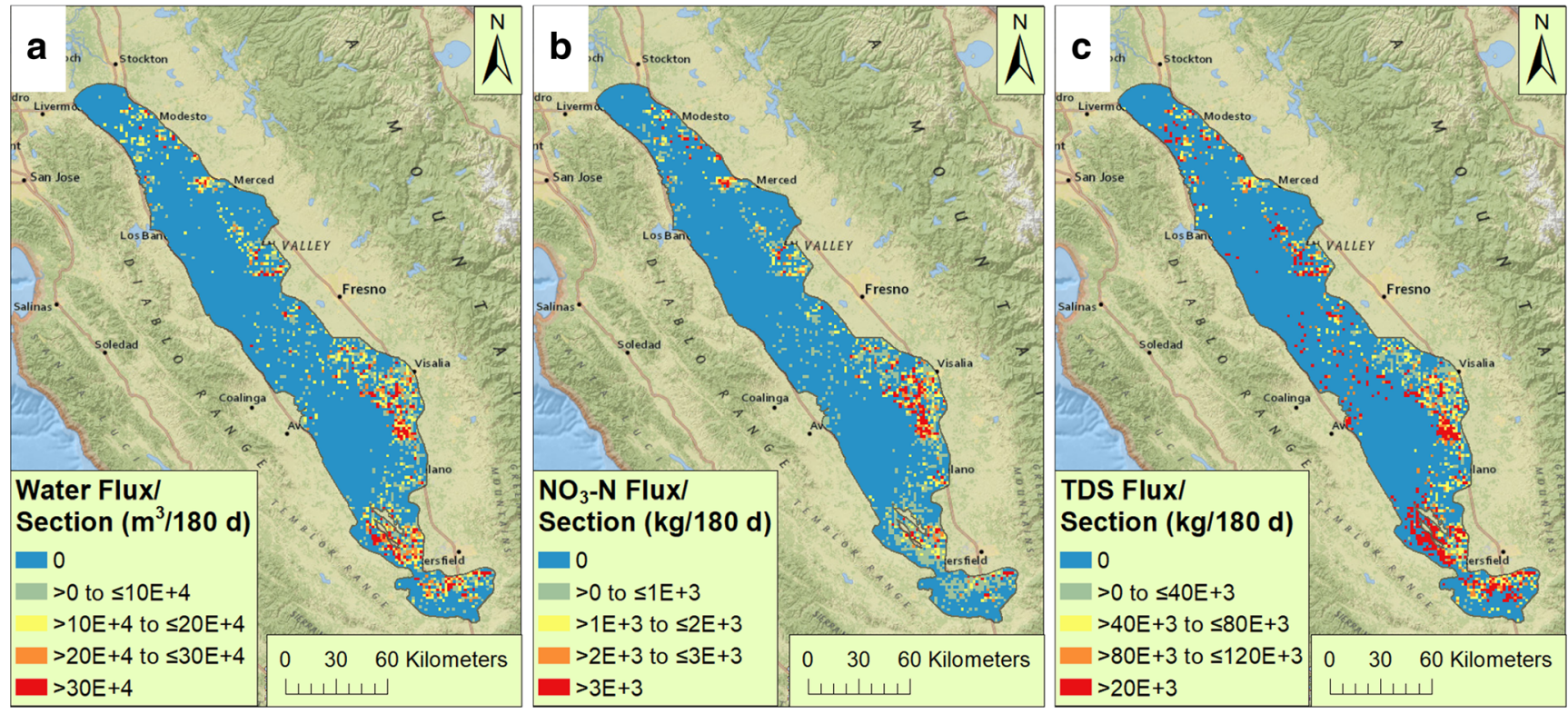

Fig. 10 Downward flows and contaminant mass transfer rates through conduit wells: a water, $\mathbf{b}$ nitrate as nitrogen and $\mathbf{c}$ total dissolved solids. Results correspond to columns on Table 3 labeled 'High' 
Fig. 11 Volumetric water flows through the aquitard and conduit well predicted by the numerical model

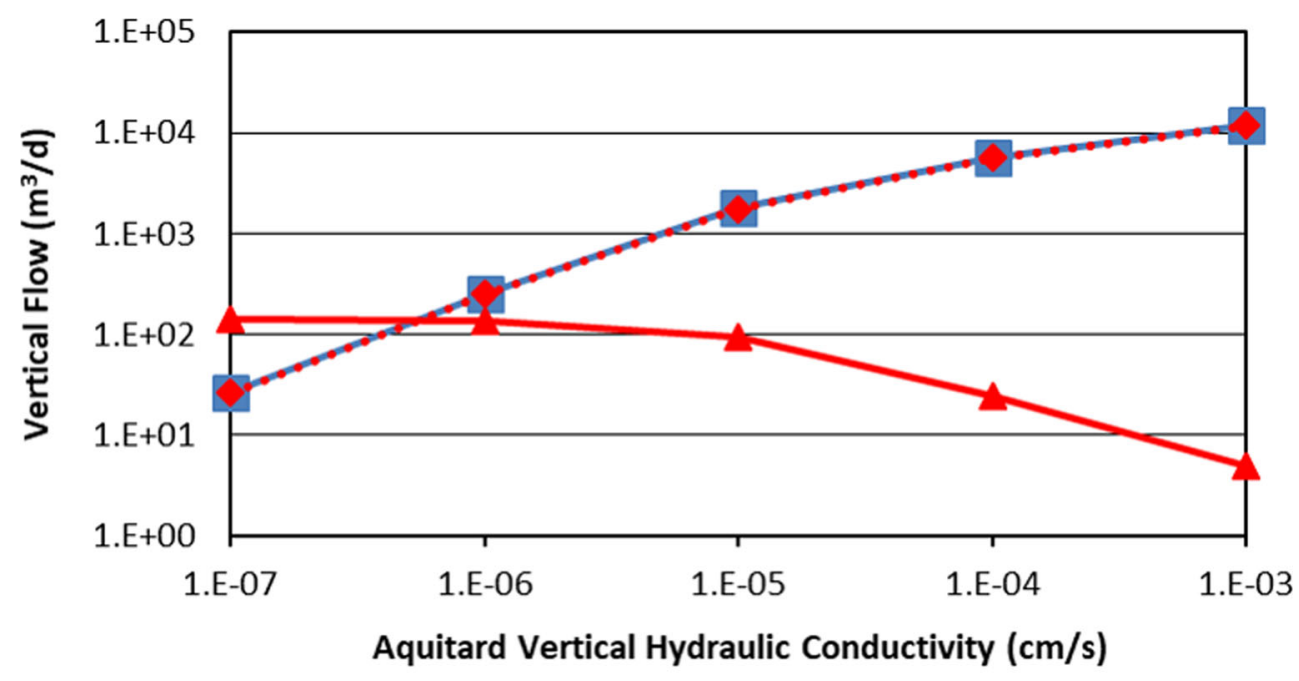

$\longrightarrow$ Aquitard w/o Well $\quad \cdots \leftrightarrow \cdot$ Aquitard w/Well $\longrightarrow$ Well
Because the flow of contaminated water through the aquitard occurs over a large area and the flux through the aquitard is relatively low (Fig. 12), mass transfer occurs in a dispersed fashion and dilution results from the horizontal flow of cleaner water in the lower aquifer. However, the level of water quality impact in the lower (receiving) aquifer from contaminant mass transfer through a conduit well is greater because it occurs as a result of a localized and higher flux. This point is clarified by considering the ratio of well to aquitard groundwater fluxes and the resulting water quality impact (Fig. 13). For cases where the aquitard conductivity is quite low (left-hand side of Fig. 13), groundwater flux through the well is much greater than through the aquitard and contaminant plumes are relatively large. Conversely, when the aquitard conductivity is close to that of the aquifers (right-hand side of
Fig. 13), there is less flux through the well relative to the aquitard and the water quality impact from the conduit well does not migrate as far from the well.

\section{Targeted approach for improvement}

Addressing all, or most, conduit wells in the study area would likely be impossible. Given the many wells and often-forgotten locations of older wells, the costs involved would limit any program of investigation and corrective action. However, the results presented here support use of a targeted approach. Review of Table 3 for each water quality constituent indicates that the maximum transfer rate in a single section is responsible for approximately 1 to $3 \%$ of the total migration through conduit wells in the study area. Additional analysis of the nitrate transfer
Fig. 12 Water fluxes through the aquitard and conduit well developed from volumetric water flows presented in Fig. 11

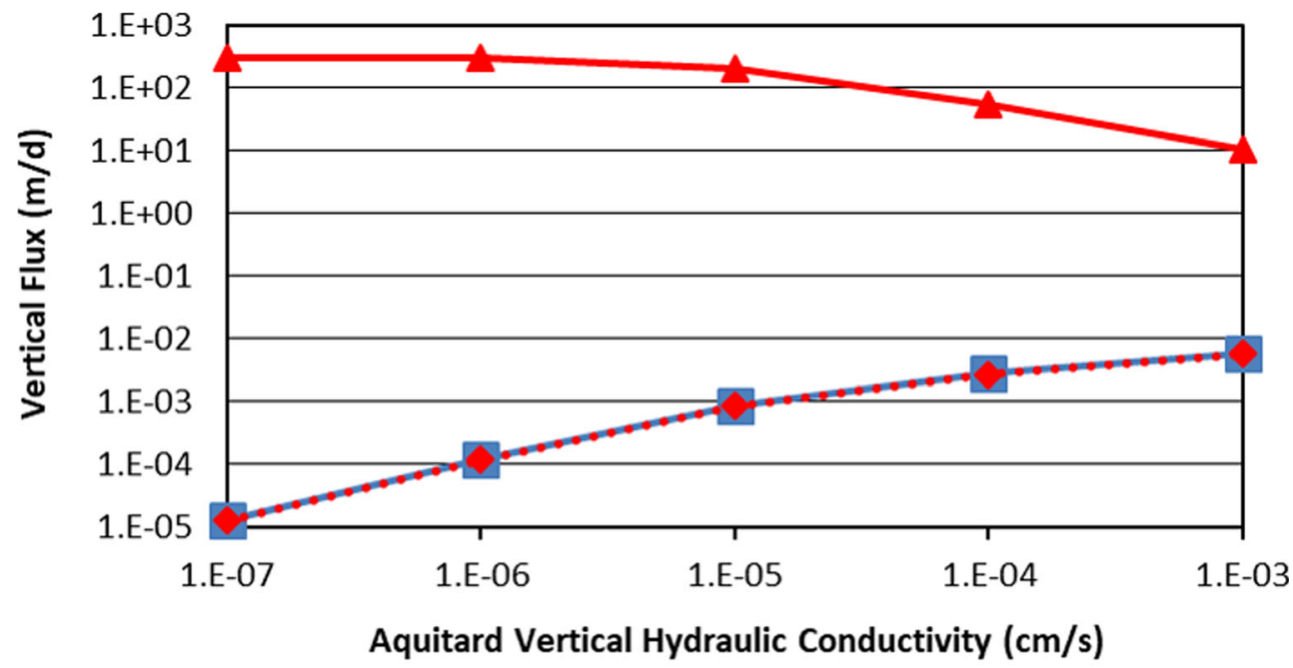

- Aquitard w/o Well $\ldots \leftrightarrow$ Aquitard w/Well $\rightarrow$ Well 
Fig. 13 Ratio of groundwater fluxes through the well and aquitard as well as resulting contaminant plume length in the lower aquifer predicted by the numerical model. Red and blue lines indicate differences in model results from changing the aquifer horizontal hydraulic conductivity by a factor of ten

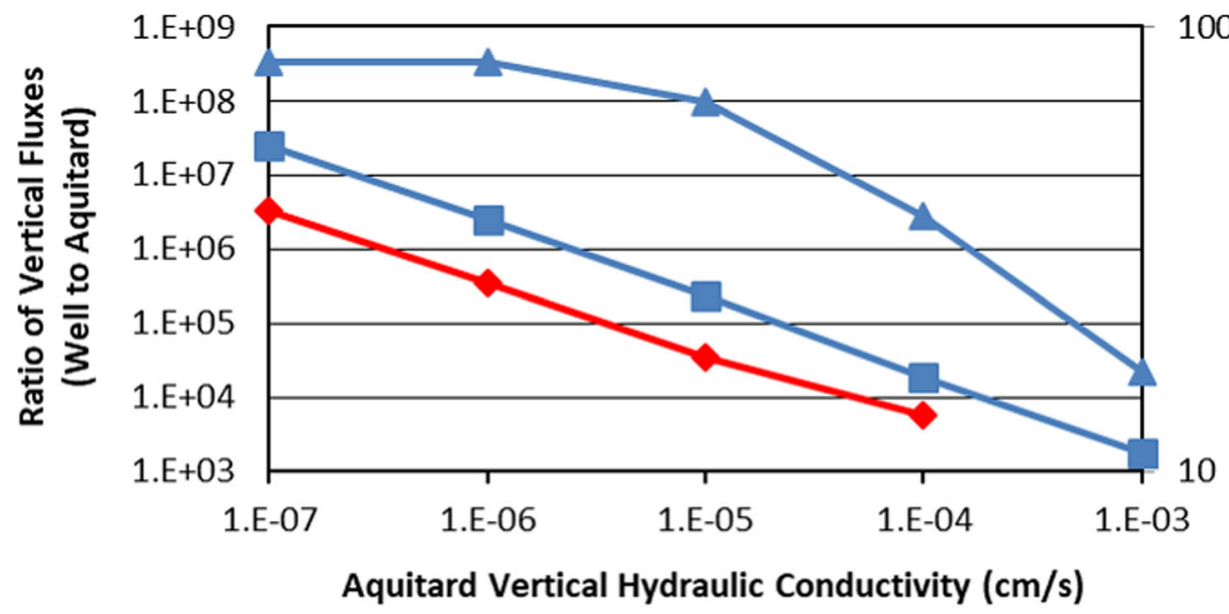

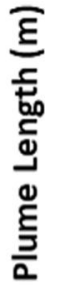

\author{
$\leftarrow$ Plume Length @ $180 \mathrm{~d}$
}

rates by section reveals that a significant amount of the areawide vertical transport for this contaminant occurs in a small number of PLSS sections (Fig. 14). Ten percent of the estimated total nitrate migration through conduit wells occurs in only ten sections. Inspection of the geographic data indicates that only 21 wells are involved. Similarly, 30\% of the transport occurs in 61 sections ( 225 wells). This information can be used to target limited areas for investigation and potential corrective action.

Consider, for example, that some of the higher nitrate transfer rates (Fig. 10b) are close to higher densities of domestic wells in the northern part of the study area (Fig. 6c). Moreover, four sections west of the city of Merced contribute notable portions of the total nitrate transport and are close to significant numbers of domestic wells (black dots on Fig. 14 and circled area on Fig. 15). Useful improvements in groundwater protection and quality might be achieved by investigating this small number of sections where contaminant transfer rates are likely to be high and only 28 wells would be involved.

\section{Conclusions}

Identifying areas where supply wells likely act as conduits for contaminant migration is fairly simple if there is access to informative data. In this case, survey-level analysis is performed for a geographically extensive area to identify the co-occurrence of (1) wells screened across a regional aquitard and (2) poor water quality in shallow strata. The number of wells that appear to act as conduits is potentially significant, even though it is a small fraction of all wells in the study area, considering (1) estimates
Fig. 14 Section contributions for well-conduit transfer of nitrate to strata beneath the clay. Results correspond to ' $\mathrm{NO}_{3}-\mathrm{N}$ high' on Table 3. Black dots indicate estimates for PLSS sections located west of Merced (shown in circled area on Fig. 15)

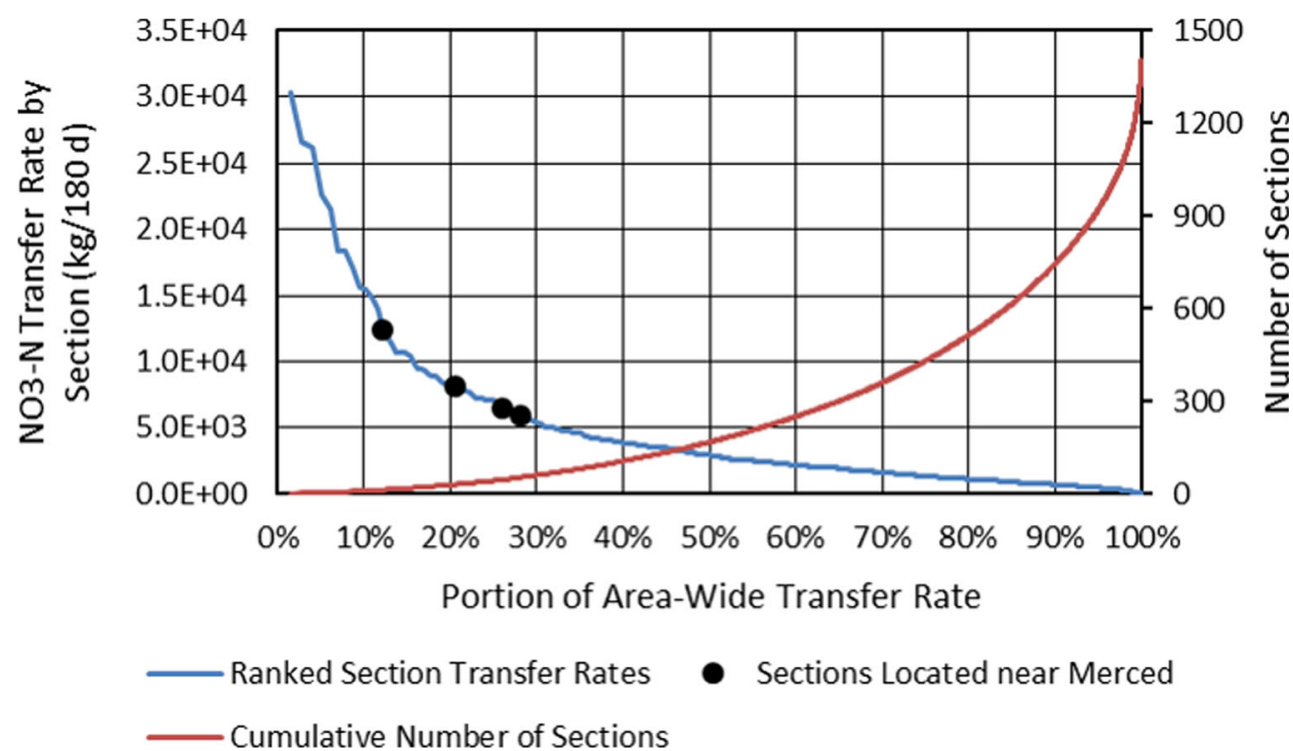


Fig. 15 Domestic wells that terminate beneath the clay as on Fig. 6c and PLSS section locations with highest nitrate transfer rates. Large black dots indicate section locations that together contribute $30 \%$ of total well conduit contaminant transfer to strata beneath clay. Circled portion contains sections with high nitrate transfer rates (shown on Fig. 14 as black dots) and nearby areas with higher densities of domestic wells

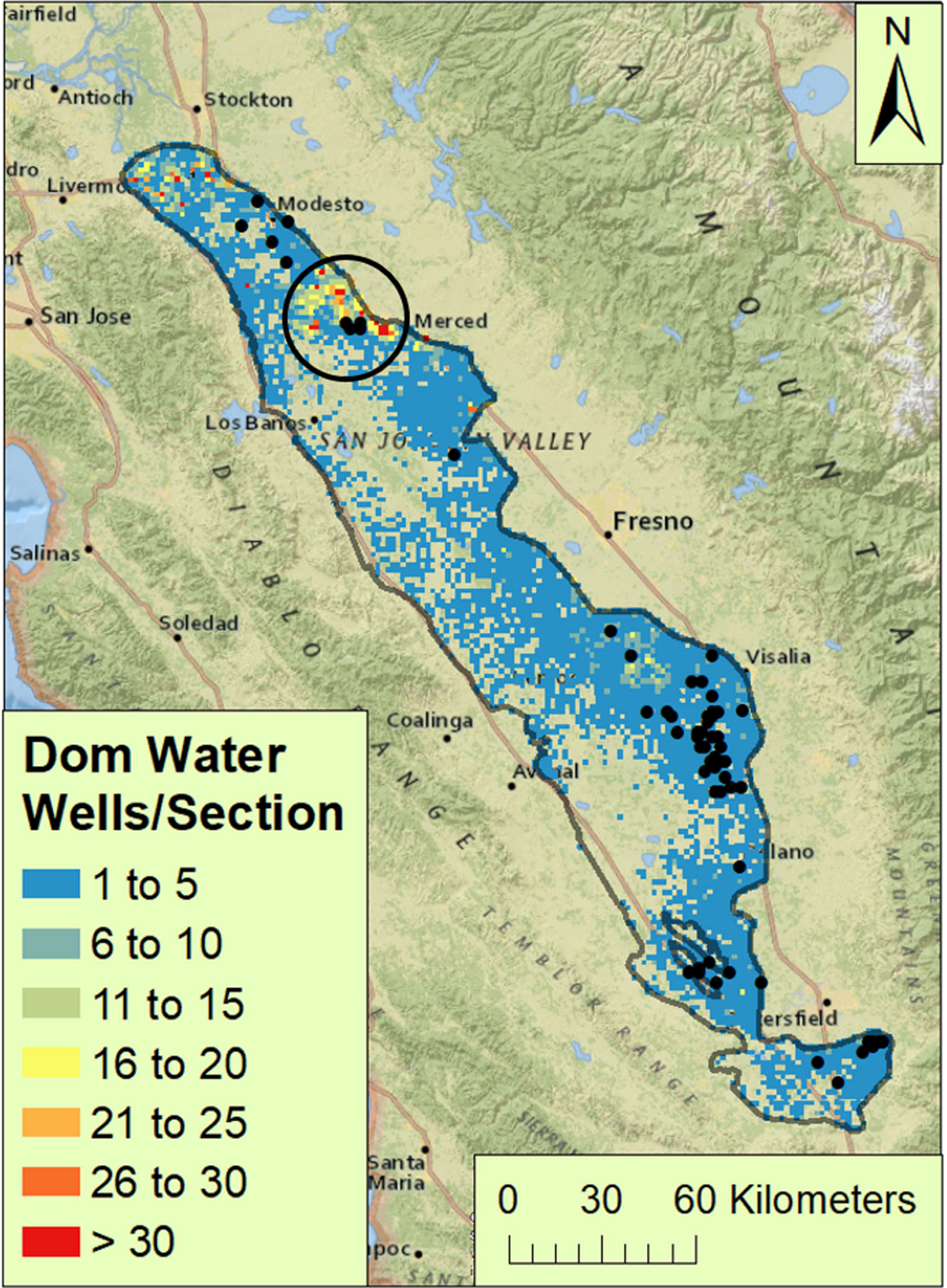

of contaminant transfer rates, (2) proximity to domestic wells and (3) the need to control nonpoint source pollution and improve drinking water quality for rural residents.

These results should be viewed within the context of the analysis performed and assumptions made (see section 'Methods of analysis'). Some false-positive and false-negative results undoubtedly occur for individual wells. Also, contaminant mass transfer rates are approximate. Nevertheless, information from the analysis provides insights regarding areas where investigation and corrective action might be best targeted.
Follow-on work guided by the geographic analysis might begin with considering information for specific wells such as (1) construction and lithologic logs prepared at the time of well completion and (2) water quality problems upon start up after idle periods (Gailey 2017). Potential responses to issues that may be revealed include structural and operational changes such as wellscreen modification or regularly scheduled pumping (Gailey 2017).

While this work focuses on a specific region, the results indicate that impacts from groups of wells may occur in other 
areas with similar, and fairly common, conditions (stratified alluvial sediments, irrigation water applied at ground surface, groundwater pumped from depth, poor shallow groundwater quality and long well screens). In these cases, geographic analysis may lead to more detailed evaluation in limited areas of concern. The potential benefits to groundwater quality may justify expenditures to develop the necessary data for performing the type of analysis demonstrated here.

Acknowledgements The author is grateful to the California Department of Water Resources for sharing data regarding the geographic distribution of water supply well construction details and the Central Valley Salinity Coalition for sharing GIS layers regarding groundwater quality. Jay Lund, Graham Fogg, Thomas Harter and three anonymous reviewers are also appreciatively acknowledged for editorial and technical comments that improved this manuscript.

Funding Information This work was supported by the UC Office of the President's Multi-Campus Research Programs and Initiatives (MR-15328473) through UC Water, the University of California Water Security and Sustainability Research Initiative and by the S.D. Bechtel Jr. Foundation through the UC Davis Center for Watershed Sciences.

\section{Appendix}

The factor for down-scaling vertical gradients across the aquitard to use in calculating flow along well casings (see section 'Evaluating geographic information' item 7b) is developed through analytical modeling. The analysis is developed similar to Silliman and Higgins (1990) with two exceptions: (1) higher head occurs in the upper aquifer so that flow is downward through the well and (2) head loss that results from flow along the well casing is addressed separately from losses that occur through the well screens. The approach is briefly described here with additional details available in Silliman and Higgins (1990). Physical relationships associated with the mathematical development are shown in Fig. 16.

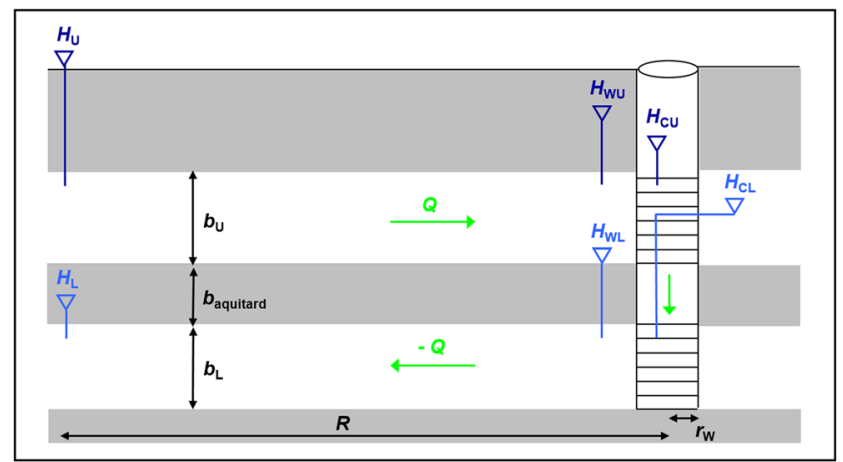

Fig. 16 Physical relationships between parameters used to estimate gradient down-scaling factor. Figure not to scale

\section{Confined conditions}

Steady-state groundwater flow to a well under confined conditions may be expressed by the Thiem equation (Bear 1979):

$H(R)-h\left(r_{\mathrm{w}}\right)=[Q /(2 \pi T)] \ln \left(R / r_{\mathrm{w}}\right)$

where the terms are as follows:

$H(\mathrm{R}) \quad$ Head at radial distance $R$, hereafter referred to as $H$

$h\left(r_{\mathrm{w}}\right) \quad$ Head at radial distance $r_{\mathrm{w}}$, hereafter referred to as $H_{\mathrm{W}}$

$Q \quad$ Exchange rate of groundwater between the aquifer and the well defined as greater than zero when groundwater flows into well

$T \quad$ Transmissivity which is further defined as $T=K b$

$K \quad$ Aquifer hydraulic conductivity

$b \quad$ Aquifer thickness

$R \quad$ The radius of influence, or the distance from the well beyond which flow in the well does not affect head in the aquifer

$r_{\mathrm{w}} \quad$ The well radius

Equation (4) is reformulated by rearranging, consolidating variables and applying the subscript $U$ to designate application to the upper aquifer:

$Q=2 \pi \alpha_{\mathrm{U}}\left(H_{\mathrm{U}}-H_{\mathrm{WU}}\right)$

where $\alpha_{\mathrm{U}}=T_{\mathrm{U}} / \ln \left(R_{\mathrm{U}} / r_{\mathrm{w}}\right)$

Equation (5) is reformulated for application to the lower aquifer as Eq. (7) by applying Eq. (6) for mass balance and using subscript $\mathrm{L}$ to indicate the lower aquifer:

$Q=Q_{\mathrm{U}}=-Q_{\mathrm{L}}$

$Q=2 \pi \alpha_{\mathrm{L}}\left(H_{\mathrm{WL}}-H_{\mathrm{L}}\right)$

Head loss that results from flow along the well casing is expressed as:

$\mathrm{HL}=H_{\mathrm{CU}}-H_{\mathrm{CL}}$

where the terms are as follows:

HL Head loss in the casing

$H_{\mathrm{CU}} \quad$ Head in the well casing adjacent to the upper aquifer

$H_{\mathrm{CL}} \quad$ Head in the well casing adjacent to the lower aquifer

Head losses that occur through the well screens are expressed as:

$\mathrm{WL}_{\mathrm{U}}=H_{\mathrm{WU}}-H_{\mathrm{CU}}$

$\mathrm{WL}_{\mathrm{L}}=H_{\mathrm{CL}}-H_{\mathrm{WL}}$

where the terms are as follows:

$\mathrm{WL}_{\mathrm{U}} \quad$ Head loss through the upper well screen

$H_{\mathrm{wU}} \quad$ Head in the upper aquifer at $r_{\mathrm{w}}$ 
$\mathrm{WL}_{\mathrm{L}} \quad$ Head loss through the lower well screen

$H_{\mathrm{WL}} \quad$ Head in the lower aquifer at $r_{\mathrm{w}}$

Combining Eqs. (7)-(10) and rearranging results in an expressions for $H_{\mathrm{WU}}$. This expression enumerates the head losses along the flow path between $H_{\mathrm{L}}$ to $H_{\mathrm{WU}}$.

$H_{\mathrm{WU}}=H_{\mathrm{L}}+Q /\left(2 \pi \alpha_{\mathrm{L}}\right)+\mathrm{WL}_{\mathrm{L}}+\mathrm{HL}+\mathrm{WL}_{\mathrm{U}}$

The casing and screen head loss components are represented in terms of the flow rate in Eqs. (12)-(14). HL is represented as in Silliman and Higgins (1990), while the WL terms are represented separately as in de Marsily (1986). These flows can be turbulent (e.g., Gailey 2017).

$\mathrm{HL}=C Q^{2}$

$\mathrm{WL}_{\mathrm{U}}=A_{\mathrm{U}} Q+B_{\mathrm{U}} Q^{2}$

$\mathrm{WL}_{\mathrm{L}}=A_{\mathrm{L}} Q+B_{\mathrm{L}} Q^{2}$

Substituting Eqs. (12)-(14) into Eq. (11) and then the resulting expression into Eq. (5) followed by rearrangement produces a quadratic equation:

$a Q^{2}+b Q+c=0$

where:

$a=\left(B_{\mathrm{U}}+B_{\mathrm{L}}+C\right)\left(2 \pi \alpha_{\mathrm{L}} \alpha_{\mathrm{U}}\right) /\left(\alpha_{\mathrm{L}}+\alpha_{\mathrm{U}}\right)$

$b=\left[\left(A_{\mathrm{U}}+A_{\mathrm{L}}\right)\left(2 \pi \alpha_{\mathrm{L}} \alpha_{\mathrm{U}}\right) /\left(\alpha_{\mathrm{L}}+\alpha_{\mathrm{U}}\right)\right]+1$

$c=-\left(H_{\mathrm{U}}-H_{\mathrm{L}}\right)\left(2 \pi \alpha_{\mathrm{L}} \alpha_{\mathrm{U}}\right) /\left(\alpha_{\mathrm{L}}+\alpha_{\mathrm{U}}\right)$

The flow rate is then found using the quadratic formula:

$Q^{*}=\left[-b+\left(b^{2}-4 a c\right)^{1 / 2}\right] /(2 a)$

The factor for down-scaling is then calculated with Eq. (20) as the ratio of the gradient in the well to the gradient across the aquitard. The gradient in the well is based on (1) an estimate of flow in the well under fairly realistic conditions with the possibility of turbulent flow (Eq. 19) and (2) a common calculation for effective hydraulic conductivity under the assumption of laminar flow (Eq. 21).

$i_{\text {well }} / i_{\text {aquitard }}=\left[Q^{*} /\left(K_{\text {well }} A_{\text {well }}\right)\right] /\left[\left(H_{\mathrm{U}}-H_{\mathrm{L}}\right) / b_{\text {aquitard }}\right]$

where the terms are as follows:

$i_{\text {well }} \quad$ Vertical hydraulic gradient in the well

$i_{\text {aquitard }}$ Vertical hydraulic gradient across the aquitard

$b_{\text {aquitard }}$ Thickness of the aquitard between the upper and lower aquifers
$K_{\text {well }} \quad$ Effective hydraulic conductivity of the well

$A_{\text {well }} \quad$ Cross sectional area of the well further defined as $\pi$ $r_{\mathrm{w}}{ }^{2}$

The effective hydraulic conductivity of the well is estimated with the Hagen-Poiseuille equation (Gailey 2017):

$K_{\text {well }}=r^{2} \rho g / 8 \mu$

where the terms are as follows:

$r$ Inner radius of the well casing or screen

$\rho$ Groundwater density

$g$ Gravitational acceleration

$\mu$ Groundwater viscosity

The value calculated with Eq. (20) is substituted for $f_{\text {scale }}$ in Eq. (3) of item $7 b$ in section 'Evaluating geographic information' for estimation of conduit flows. Directly substituting the expression in Eq. (20) for $f_{\text {scale }}$ in Eq. (3) of item 7b and simplifying reveals that the hydraulic conductivity terms ( $K_{\text {well }}$, which involve the assumption of laminar flow, cancel out of the final expression for estimated flow rate through the well:

$Q_{\text {well_est }}=\left[\left(Q^{*} b_{\text {aquitard }}\right) /\left(H_{\mathrm{U}}-H_{\mathrm{L}}\right)\right] i_{\text {clay }}$

Therefore, there is no potential conflict in assuming turbulent flow when calculating $Q^{*}$ and laminar flow when calculating $K_{\text {well }}$.

\section{Unconfined conditions}

For unconfined conditions, Dupuit's solution is used (Silliman and Higgins 1990; de Marsily 1986) and Eq. (5) is replaced with:

Table 4 Parameter values for the base case

\begin{tabular}{lllll}
\hline Parameter & Units & Upper aquifer & Lower aquifer & Well loss \\
\hline$H$ & $\mathrm{~m}$ & 100 & 50 & - \\
$K$ & $\mathrm{~m} / \mathrm{s}$ & $10^{-5}$ & $10^{-5}$ & - \\
$b$ & $\mathrm{~m}$ & 60 & 100 & - \\
$T$ & $\mathrm{~m}^{2} / \mathrm{s}$ & $6 \times 10^{-4}$ & $10^{-3}$ & - \\
$b_{\text {aquitard }}$ & $\mathrm{m}$ & 30 & 30 & - \\
$R$ & $\mathrm{~m}$ & 40 & 40 & - \\
$r_{\mathrm{w}}$ & $\mathrm{m}$ & 0.2 & 0.2 & - \\
$A_{\mathrm{U}}$ & $\mathrm{s} / \mathrm{m}^{2}$ & - & - & 100 \\
$A_{\mathrm{L}}$ & $\mathrm{s} / \mathrm{m}^{2}$ & - & - & 100 \\
$B_{\mathrm{U}}$ & $\mathrm{s}^{2} / \mathrm{m}^{5}$ & - & - & 100 \\
$B_{\mathrm{L}}$ & $\mathrm{s}^{2} / \mathrm{m}^{5}$ & - & - & 100 \\
$e$ & $\mathrm{~m}$ & - & - & $2.5 \times 10^{-2}$ \\
$f$ & - & - & - & 0.08 \\
$C$ & $\mathrm{~s}^{2} / \mathrm{m}^{5}$ & - & - & 17.8 \\
\hline
\end{tabular}




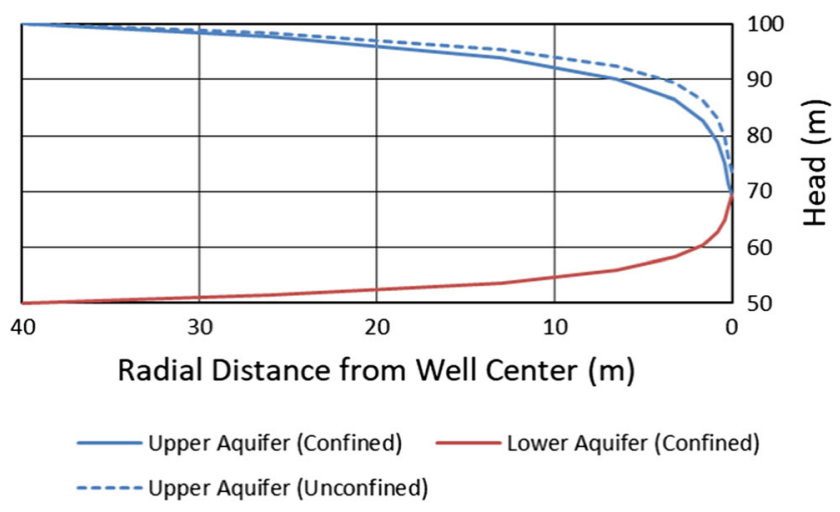

Fig. 17 Calculated aquifer head profiles

$Q=\pi \alpha_{\mathrm{U}}\left(H_{\mathrm{U}}^{2}-H_{\mathrm{WU}}^{2}\right)$

where $\alpha_{\mathrm{U}}=K_{\mathrm{U}} / \ln \left(R_{\mathrm{U}} / r_{\mathrm{w}}\right)$.

Conservation of mass is expressed by combining Eqs. (23) and (7):

$\pi \alpha_{\mathrm{U}}\left(H_{\mathrm{U}}^{2}-H_{\mathrm{WU}}^{2}\right)=2 \pi \alpha_{\mathrm{L}}\left(H_{\mathrm{WL}}-H_{\mathrm{L}}\right)$

Substituting the head loss terms from Eqs. (8)-(10) for $H_{\mathrm{WL}}$ and expressing in terms of flow rate according to Eqs. (12)-(14):

$$
\begin{aligned}
& \pi \alpha_{\mathrm{U}}\left(H_{\mathrm{U}}^{2}-H_{\mathrm{WU}}^{2}\right) \\
& \quad=2 \pi \alpha_{\mathrm{L}}\left[H_{\mathrm{WU}}-\left(A_{\mathrm{U}}+A_{\mathrm{L}}\right) Q-\left(B_{\mathrm{U}}+B_{\mathrm{L}}+C\right) Q^{2}-H_{\mathrm{L}}\right]
\end{aligned}
$$

Substituting the expression for flow rate in Eq. (23) for instances of Q in Eq. (25) and rearranging results in a fourth-order polynomial in $H_{\mathrm{wU}}$ :

$D_{1} H_{\mathrm{wU}}^{4}+D_{2} H_{\mathrm{wU}}^{2}+D_{3} H_{\mathrm{wU}}+D_{4}=0$

where:

$D_{1}=-2 \pi^{3} \alpha_{\mathrm{U}}^{2} \alpha_{\mathrm{L}}\left(B_{\mathrm{U}}+B_{\mathrm{L}}+C\right)$

$$
\begin{aligned}
D_{2}= & 2 \pi^{2} \alpha_{\mathrm{U}} \alpha_{\mathrm{L}}\left(A_{\mathrm{U}}+A_{\mathrm{L}}\right) \\
& +4 \pi^{3} \alpha_{\mathrm{U}}^{2} \alpha_{\mathrm{L}}\left(B_{\mathrm{U}}+B_{\mathrm{L}}+C\right) H_{\mathrm{U}}^{2}+\pi \alpha_{\mathrm{U}} \\
\mathrm{D}_{3}= & 2 \pi \alpha_{\mathrm{L}} \\
\mathrm{D}_{4}= & -2 \pi^{2} \alpha_{\mathrm{U}} \alpha_{\mathrm{L}}\left(A_{\mathrm{U}}+A_{\mathrm{L}}\right) H_{\mathrm{U}}^{2}-2 \pi^{3} \alpha_{\mathrm{U}}^{2} \alpha_{\mathrm{L}} \\
& \left(B_{\mathrm{U}}+B_{\mathrm{L}}+C\right) H_{\mathrm{U}}^{4}-2 \pi \alpha_{\mathrm{L}} H_{\mathrm{L}}-\pi \alpha_{\mathrm{U}} H_{\mathrm{U}}^{2}
\end{aligned}
$$

Solving for $H_{\mathrm{WU}}$ and substituting into Eq. (23) provides an estimate for flow rate. Equations (20) and (21) in section 'Confined conditions' can then be used to calculate the factor for down-scaling.

\section{Estimating the down-scaling factor value}

The downscaling factor from Eq. (20) was estimated for confined conditions using a reasonable set of parameter values for the study area. Sensitivity analysis was performed by adjusting the parameter values and also considering unconfined conditions. Table 4 summarizes the parameter values used for the base case.

Consistent with the possibility that turbulent flow may occur inside the well casing, the value for head loss in the well casing ( $C$ in Eq. 12) was developed using the Darcy-Weisbach equation (Vennard and Street 1982):

$\mathrm{HL}=f\left[L /\left(4 \pi^{2} g r_{\mathrm{w}}{ }^{5}\right)\right] Q^{2}$

where the terms are as follows:

$f$ Friction factor

$L \quad$ Length of well casing which is equal to $b_{\text {aquitard }}$ in this case (Fig. 16)

The friction factor was estimated by implicit solution of the

\begin{tabular}{|c|c|c|c|c|c|c|c|}
\hline Parameter & $T_{\mathrm{U}}$ & $T_{\mathrm{L}}$ & $R$ & $b_{\text {aquitard }}$ & $f$ & $A$ & $B$ \\
\hline Base case & $1.9 \times 10^{-6}$ & $1.9 \times 10^{-6}$ & $1.9 \times 10^{-6}$ & $1.9 \times 10^{-6}$ & $1.9 \times 10^{-6}$ & $1.9 \times 10^{-6}$ & $1.9 \times 10^{-6}$ \\
\hline Increased result & $3.8 \times 10^{-6}$ & $2.7 \times 10^{-6}$ & $1.7 \times 10^{-6}$ & $3.7 \times 10^{-6}$ & $1.9 \times 10^{-6}$ & $1.1 \times 10^{-6}$ & $1.8 \times 10^{-6}$ \\
\hline Decreased result & $3.0 \times 10^{-7}$ & $4.6 \times 10^{-7}$ & $2.1 \times 10^{-6}$ & $9.4 \times 10^{-7}$ & $1.9 \times 10^{-6}$ & $2.0 \times 10^{-6}$ & $1.9 \times 10^{-6}$ \\
\hline
\end{tabular}
Colebrook equation (Vennard and Street 1982):

$$
\begin{aligned}
& 1 / f^{1 / 2}-2 \log \left(r_{\mathrm{w}} / 2 e\right) \\
& \quad=1.14-2 \log \left[1+9.28 /\left(\operatorname{Re}\left(2 e / r_{\mathrm{w}}\right) f^{1 / 2}\right)\right]
\end{aligned}
$$

where the terms are as follows:

$e \quad$ Mean height of casing roughness

Table 5 Sensitivity analysis for $i_{\text {well }} / i_{\text {aquitard }}$ under confined conditions

Factors used to increase parameter values: $T_{\mathrm{U}}: 10, T_{\mathrm{L}}: 10, R: 2, b_{\text {aquitard }}: 2, f: 10, A: 10$ and $B: 10$

Factors used to decrease parameter values: $T_{\mathrm{U}}: 0.1, T_{\mathrm{L}}: 0.1, R: 0.5, b_{\text {aquitard }}: 0.5, f: 0.1, A: 0.1$ and $B: 0.1$ 
Re Reynolds number defined as follows (Vennard and Street 1982):

$\operatorname{Re}=(2 \rho Q) /(\pi \mu r)$

The head profiles for upper and lower aquifers using base case parameter values (Fig. 17) illustrate the effects of head losses from radial flow, friction in the well screens and friction in the casing. The sensitivity results for confined conditions (Table 5) and the base case result for unconfined conditions $\left(2.3 \times 10^{-6}\right)$ indicate that the down-scaling factor is not highly sensitive to reasonable variations in the parameter values. Given that semiconfined conditions exist in the study area, a value between the confined and unconfined base case results was used $\left(2.0 \times 10^{-6}\right)$.

Open Access This article is distributed under the terms of the Creative Commons Attribution 4.0 International License (http:// creativecommons.org/licenses/by/4.0/), which permits unrestricted use, distribution, and reproduction in any medium, provided you give appropriate credit to the original author(s) and the source, provide a link to the Creative Commons license, and indicate if changes were made.

\section{References}

Bear J (1979) Hydraulics of groundwater. McGraw-Hill, New York, NY Belitz K, Heimes FJ (1990) Character and evolution of the ground-water flow system in the central part of the western San Joaquin Valley, California. US Geol Surv Water Supply Pap 2348

CADWR (1981) Depth to the top of Corcoran clay: 1981. http:// wwwwatercagov/pubs/groundwater/depth to top_of_corcoran clay_map_1981/depth_to_the_top_of_corcoran_clay-1981pdf. Accessed 11 May 2017

CADWR (2016) Critically overdrafted groundwater basins: January 2016. http://www.water.ca.gov/groundwater/sgm/pdfs/GW basinsCriticalOverdraft CA.pdf. Accessed 11 May 2017

CADWR (2017a) Groundwater level data reports. http://www.water.ca. gov/waterdatalibrary/groundwater/index.cfm. Accessed 11 May 2017

CADWR (2017b) Well completion report map application. https:// dwrmapsarcgiscom/apps/webappviewer/indexhtml?id= 181078580a214c0986e2da28f8623b37. Accessed 28 November 2017

Cantor A, Kiparsky M, Bales R, Hubbard S, Kennedy R, Pecharroman LC (2018) Data for water decision making: informing the implementation of California's open and transparent water data act through research and engagement. Center for Law, Energy \& the Environment, UC Berkeley School of Law, Berkeley, CA

Clark BR, Landon MK, Kauffman LJ and Hornberger GZ (2008) Simulations of ground-water flow, transport, age, and particle tracking near York, Nebraska, for a study of transport of anthropogenic and natural contaminants (TANC) to public supply wells. US Geol Surv Sci Invest Rep 2007-5068

CVSC (2016) Central Valley salinity alternatives for long-term sustainability. Central Valley region salt and nitrate management plan, final document for Central Valley Regional Water Board consideration,
December 2016. https://wwwcvsalinityorg/docs/central-valleysnmp/final-snmphtml. Accessed 11 May 2017

Davis GH, Lofgren BE, Mack S (1964) Use of ground-water reservoirs for storage of surface water in the San Joaquin Valley California. US Geol Surv Water Supply Pap 1618

de Marsily G (1986) Quantitative hydrogeology, groundwater hydrology for engineers. Academic Press, San Diego, CA

Faunt CC (ed) (2009) Groundwater availability of the Central Valley aquifer, California. US Geol Surv Prof Pap 1766

Faunt CC (2012) Contours of Corcoran Clay thickness in feet by Page (1986) for the Central Valley Hydrologic Model (CVHM). US Geol Surv Water Resour NSDI Node. https://water.usgs.gov/GIS/ metadata/usgswrd/XML/pp1766_corcoran_clay_thickness_feet. xml. Accessed 11 May 2017

Gailey RM (2017) Inactive supply wells as conduits for flow and contaminant migration: conditions of occurrence and suggestions for management. Hydrogeol J 25(7):2163-2183. https://doi.org/10. 1007/s10040-017-1588-y

Hanak E, Lund J, Arnold B, Escriva-Bou A, Gray B, Green S, Harter H, Howitt R, MacEwan D, Meddellin Azuara Moyle P, Seavey N (2017) Water stress and a changing San Joaquin Valley, Public Policy Institute of California, March 2017. http://wwwppicorg/ main/publicationasp?i=1224. Accessed 11 May 2017

Jasechko S, Perrone D, Befus KM, Cardenas MB, Ferguson G, Gleeson T, Luijendijk E, McDonnell JJ, Taylor RG, Wada Y, Kirchner JW (2017) Global aquifers dominated by fossil groundwaters but wells vulnerable to modern contamination. Nat Geosci 10(6):425-429. https://doi.org/10.1038/ngeo2943

Jurgens BC, Bexfield LM, Eberts SM (2014) A ternary age-mixing model to explain contaminant occurrence in a deep supply well. Ground Water 52(S1):25-39. https://doi.org/10.1111/gwat.12170

Landon MK, Jurgens BC, Katz BG, Eberts SM, Burow KR, Crandall CA (2009) Depth-dependent sampling to identify short-circuit pathways to public supply wells in multiple aquifer settings in the United States. Hydrogeol J 18(3):577-593. https://doi.org/10.1007/ s10040-006-0148-7

Mayo AL (2010) Ambient well-bore mixing, aquifer cross-contamination, pumping stress and water quality from long-screened wells: what is sampled and what is not? Hydrogeol J 18:823-837. https:// doi.org/10.1007/s10040-009-0568-2

Moore E, Matalon E, Balazs C, Clary J, Firestone L, De Anda S, Guzman $\mathrm{M}$ (2011) The human costs of nitrate-contaminated drinking water in the San Joaquin Valley. Pacific Institute, Oakland, CA

Page RW (1986) Geology of the fresh ground-water basin of the Central Valley. California, with textural maps and sections. US Geol Surv Prof Pap 1401-C. https://pubsusgsgov/pp/1401c/reportpdf. Accessed 11 May 2017

Perrone D, Jasechko S (2017) Dry groundwater wells in the western United States. Environ Res Lett 12:104002

Phillips SP, Belitz K (1991) Calibration of a texture-based model of a ground-water flow system, western San Joaquin Valley, California. Ground Water 29(5):702-715. https://doi.org/10.1111/j.1745-6584. 1991.tb00562.x

Silliman S, Higgins D (1990) An analytical solution for steady-state flow between aquifers through an open well. Ground Water 28(2):184 190. https://doi.org/10.1111/j.1745-6584.1990.tb02245.x

Vennard JK, Street RL (1982) Elementary fluid mechanics, 6th edn. Wiley, New York, NY

Zuurbier KG, Stuyfzand PJ (2017) Consequences and mitigation of saltwater intrusion induced by short-circuiting during aquifer storage and recovery in a coastal subsurface. Hydrol Earth Syst 21:11731188. https://doi.org/10.5194/hess-21-1173-2017 